\title{
CAM-DR: Mechanisms, Roles and Clinical Application in Tumors
}

\author{
Yuejiao Huang ${ }^{1,2+}$, Yuchan Wang ${ }^{3+}$, Jie Tang ${ }^{3}$, Shiyi Qin ${ }^{1,4}$, Xianjuan Shen ${ }^{4}$, Song He ${ }^{5 *}$ and \\ Shaoqing $\mathrm{Ju}^{1,4 *}$
}

${ }^{1}$ Medical School, Nantong University, Nantong, China, ${ }^{2}$ Department of Medical Oncology, Affiliated Tumor Hospital of Nantong University, Nantong, China, ${ }^{3}$ Department of Pathogenic Biology, School of Medicine, Nantong University, Nantong, China, ${ }^{4}$ Department of Laboratory Medicine, Affiliated Hospital of Nantong University, Nantong, China,

${ }^{5}$ Department of Pathology, Affiliated Tumor Hospital of Nantong University, Nantong, China

OPEN ACCESS

Edited by: Giuseppe Fiume,

Magna Græcia University

of Catanzaro, Italy

Reviewed by:

Hamid Morjani,

Université de Reims

Champagne-Ardenne, France

Marilena Celano,

Magna Græcia University

of Catanzaro, Italy

*Correspondence:

Shaoqing Ju

jsq814@hotmail.com

Song $\mathrm{He}$

ntzlyyhesong515@ntu.edu.com

${ }^{t}$ These authors have contributed equally to this work

Specialty section:

This article was submitted to Molecular Medicine,

a section of the journal Frontiers in Cell and Developmental Biology

Received: 21 April 2021 Accepted: 08 June 2021

Published: 06 July 2021

Citation:

Huang $Y$, Wang $Y$, Tang J, Qin S, Shen X, He S and Ju S (2021) CAM-DR: Mechanisms, Roles and Clinical Application in Tumors. Front. Cell Dev. Biol. 9:698047. doi: 10.3389/fcell.2021.698047
Despite the continuous improvement of various therapeutic techniques, the overall prognosis of tumors has been significantly improved, but malignant tumors in the middle and advanced stages still cannot be completely cured. It is now evident that cell adhesion-mediated resistance (CAM-DR) limits the success of cancer therapies and is a great obstacle to overcome in the clinic. The interactions between tumor cells and extracellular matrix (ECM) molecules or adjacent cells may play a significant role in initiating the intracellular signaling pathways that are associated with cell proliferation, survival upon binding to their ligands. Recent studies illustrate that these adhesionrelated factors may contribute to the survival of cancer cells after chemotherapeutic therapy, advantageous to resistant cells to proliferate and develop multiple mechanisms of drug resistance. In this review, we focus on the molecular basis of these interactions and the main signal transduction pathways that are involved in the enhancement of the cancer cells' survival. Furthermore, therapies targeting interactions between cancer cells and their environment to enhance drug response or prevent the emergence of drug resistance will also be discussed.

\section{Keywords: CAM-DR, tumor microenvironment, hematologic malignancies, signaling pathways, inhibitors}

Abbreviations: EM-DR, environment-mediated drug resistance; SM-DR, soluble factor mediated-drug resistance; CAMDR, cell adhesion mediated-drug resistance; NHL, non-Hodgkin's lymphoma; MM, multiple myeloma; VEGF, vascular growth factor; IL-3, IL-6, interleukin-3, 6; NO, nitric oxide; G-CSF, granulocyte colony-stimulating factor; BAFF, B cellactivating factor of the TNF family; GM-CSF, granulocyte-macrophage colony-stimulating factor; Bcl-2, B cell lymphoma-2; FN, fibronectin; VCAM-1, vascular cell adhesion molecule-1; VLA-4, integrin very late antigen-4; DDR, discoidin domain receptor; CXCR, C-X-C motif chemokine receptors; BMSCs, bone marrow stromal cells; MGUS, monoclonal gammopathy of unknown significance; SMM, smoldering multiple myeloma; HDACs, histone deacetylases; CAFs, cancer-associated fibroblasts; MDR, multi-drug resistance; BL, Burkitt's lymphoma; MCL, mantle cell lymphoma; ALL, acute lymphocytic leukemia; CLL, chronic lymphocytic leukemia; AML, acute myeloid leukemia; CML, chronic myeloid leukemia; ABCC1, ATP-binding cassette C 1; PI3K, phosphatidylinositol 3-kinase; BTK, Bruton tyrosine kinase; CDC25A, M-phase inducer phosphatase 1; MRD, minimal residual diseases; HCC, hepatocellular carcinoma; CTGF, connective tissue growth factor; COL1A1, collagen 1A1; OSCC, oral squamous cell carcinoma; NPC, nasopharyngeal carcinoma; ECM, extracellular matrix; GC, gastric cancer; FAK, focal adhesion kinase; MAPK, mitogen-activated protein kinase; COL1, collagen type 1; NSCLC, non-small cell lung cancer; SCLC, small-cell lung cancer; GBM, glioblastoma multiforme; CRPC, castration-resistant prostate cancer; PFS, progression-free survival; OS, overall survival; JAK, Janus-activated kinase; STAT, signal transduction and activator of transcription; iNHL, inert non-Hodgkin's Lymphoma; ORR, overall remission rate; SLL, small lymphocytic lymphoma; FL, follicular lymphoma; BTZ, bortezomib; PDGFR- $\beta$, platelet-derived growth factor receptor- $\beta$. 


\section{INTRODUCTION}

Chemotherapy remains the major treatment of disseminated cancer including hematologic malignancies and metastatic solid tumors. Intrinsic and acquired resistance disseminated continues to be a considerable obstacle on our way to improve patient cures. Resistance mechanisms originate from pathological changes of intrinsic factors such as genetics, epigenetics, transcriptional regulation, and protein activation as well as extrinsic factors including the immune system, hypoxia, metabolism, and extracellular matrix (ECM). It was proposed that the tumor microenvironment, the non-cancerous cells, and ECM that are in direct contact with the cancer cell, may influence how cancer cells respond to chemotherapy. This influence mainly involves two aspects: a soluble factor and a contact factor. The first aspect involves soluble mediators, such as interleukins, that are secreted by non-tumor, stromal cells. It is capable of providing further signals for tumor cell growth and survival. The second aspect of tumor cell-environment interaction requires direct cell contact and has been given the term cell-adhesion-mediated drug resistance (CAM-DR). Recently, attention has been focused mainly on the effect of CAM-DR and cell adhesion to ECM proteins has been well clarified as a key and fundamental determinant of cancer therapy resistance. Adhesive interactions between cells or cells and ECM can influence cell behavior and tumor cell adhesion may influence cell survival and prevent druginduced apoptosis. In this review, we will describe the current knowledge about cell adhesion resistance and put these findings into a clinical context and discuss the resulting consequences for the design of novel therapeutic strategies.

\section{MICROENVIRONMENT AND CAM-DR}

The tumor microenvironment includes a non-cellular compartment formed by ECM proteins (i.e., laminin, fibronectin, and collagen) and soluble factors (i.e., cytokines, growth factors, chemokines, exosomes, and miRNAs), and a rich cellular compartment constituted by tumor cells and stromal cells (i.e., fibroblasts, osteoclasts, endothelial cells, and mesenchymal stromal cells) (Manier et al., 2012) (Figure 1). The tumor microenvironment provides support for the growth, proliferation, and invasion of tumor cells through intercellular connections and molecular interactions. Moreover, the tumor microenvironment plays an important role in drug resistance (Burger et al., 2009). Studies have found that hematologic malignant tumor cells die rapidly in vitro, which confirms the importance of the tumor microenvironment for tumor cell survival (Li and Dalton, 2006). A growing body of experimental data shows that hematological tumor cells can survive significantly longer when co-cultured with stromal cells in vitro. Within or surrounding the malignant tumor cells, stromal cells, lymphocytes, and endothelial cells are present which interact with each other and/or with the tumor cells. Besides, soluble factors in the tumor microenvironment provide signals for cell growth and survival. The cross-talk between tumor cells and stromal cells is regulated by different mechanisms: (i) cell-to-cell adhesion between tumor cells and ECM components/stromal cells; and (ii) soluble factors, released by the stromal cells and MM cells, with autocrine and paracrine effects (Di Marzo et al., 2016). Thus, microenvironment mediated-drug resistance (EM-DR) in tumor cells can generally be divided into the intrinsic soluble factor mediated-drug resistance (SM-DR) and cell adhesion mediated-drug resistance (CAM-DR).

It has been reported that many soluble factors in the tumor microenvironment are related to the growth and survival of cells, such as vascular growth factor (VEGF) (Dias et al., 2002), interleukin-3, 6 (IL-3; IL-6) (Lee et al., 2004; Karakasheva et al., 2018), nitric oxide (NO) (Vedenko et al., 2020), granulocyte colony-stimulating factor (G-CSF) (Karagiannidis et al., 2021), B cell-activating factor of the TNF family (BAFF) (Lwin et al., 2009), etc. These soluble factors can not only stimulate the proliferation and survival of tumor cells but also lead to drug resistance. However, inhibition of these known soluble factor-mediated cell survival pathways does not overcome the phenomenon of drug resistance. Drug resistance mechanisms are multifaceted, such as gene mutations, cell cycle arrest, or CAM-DR through direct cell-to-cell contact and adhesion (Oshiro et al., 2001).

Compared with SM-DR in the tumor microenvironment, CAM-DR plays a greater role in the drug resistance of tumor cells. On the one hand, cell adhesion activates key signaling pathways leading to the expression of soluble factors and their receptors. For example, the interaction between hematologic tumor cells and stromal cells stimulates bone marrow stromal cells (BMSCs) to secrete IL-6 and granulocyte-macrophage colony-stimulating factor (GM-CSF), while MM tumor cells secrete IL-6 and VEGF, etc. (Dalton, 2003). On the other hand, cell adhesion can lead to changes that cannot be caused by soluble factors. For example, reactivation of the expression of key molecules involved in drug resistance, such as the anti-apoptotic molecule c-FLIP ${ }_{L}$, leads to Fas-mediated apoptosis (Shain et al., 2002). Another example is topoisomerase II- $\beta$, a key enzyme involved in the repair of DNA double-strand breaks, which can lead to drug resistance of tumor cells (Hazlehurst et al., 2001; Said et al., 2012). It also includes the increased expression of B cell lymphoma-2 (Bcl2) and the activation of downstream signaling pathways (Yan et al., 2015), and so on, which represents a new mechanism of drug resistance. Cell adhesion is mediated by several families of adhesion molecules, including the immunoglobulin superfamily, integrins, cadherins, and selectins (Kim et al., 2020). The tumor microenvironment is abundant in binding partners for cell adhesion molecules as each component discussed above expresses diverse ligands and secret ECM (Malara et al., 2014; Galan-Diez et al., 2018; Zhao et al., 2019) (Figure 1). Fibronectin (FN), collagen, and laminin will interact with cell surface molecules (Zhang et al., 2019). Integrins are the most widely studied molecule at present (Elliott and Sethi, 2002). Integrin is a heterodimer receptor composed of two subunits $\alpha$ and $\beta$. Up to now, $18 \alpha$ subunits and $8 \beta$ subunits have been identified (Miranti and Brugge, 2002). The expression of typical integrins is mainly $\alpha 4 \beta 1$ (integrin very late antigen-4, VLA-4) and $\alpha 5 \beta 1$ (VLA-5) in hematologic malignancies, especially VLA-4 is highly expressed in multiple myeloma (MM) cells and most normal B lymphocytes (Mraz et al., 2011). In myeloma cells, overexpression 


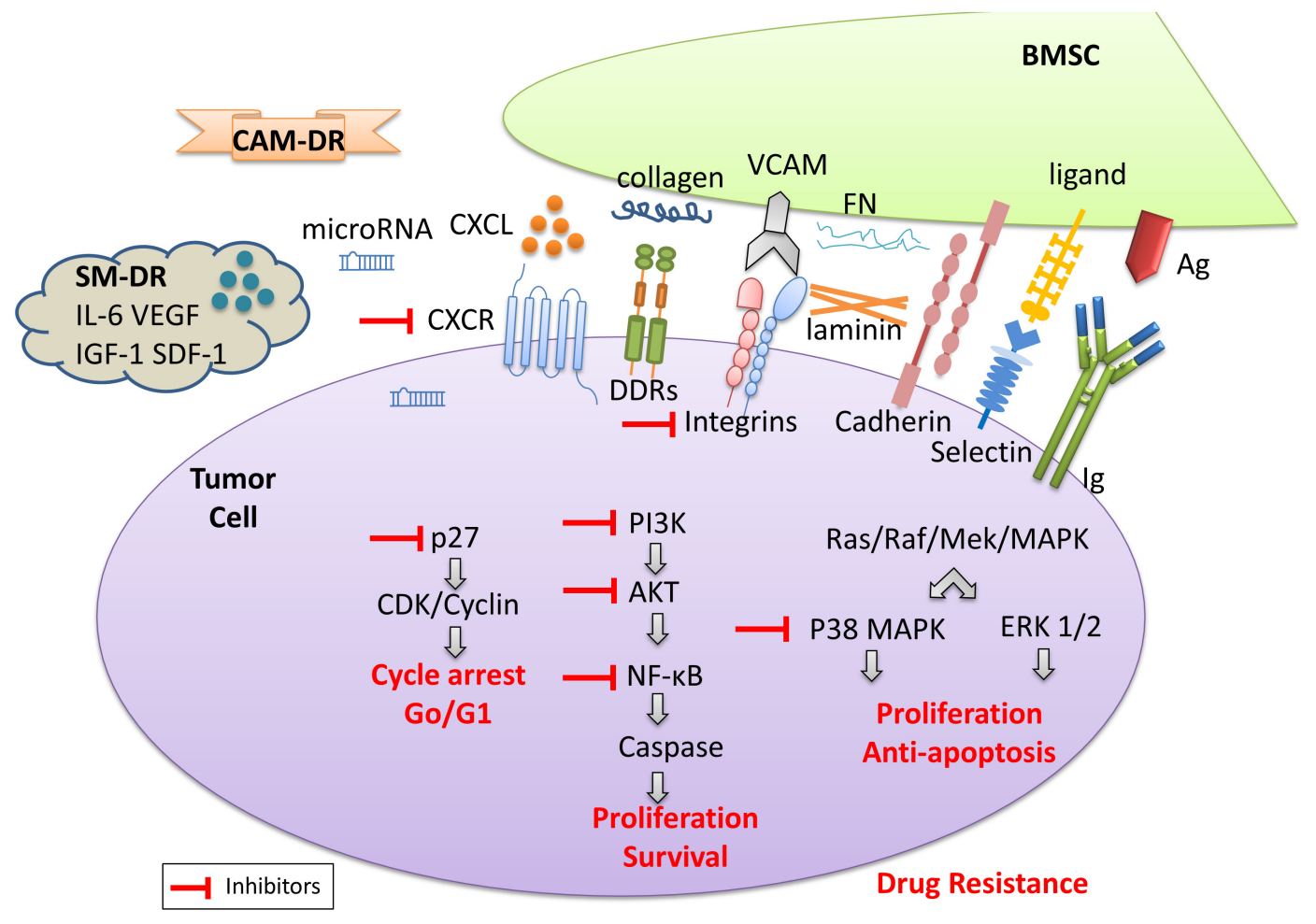

FIGURE 1 | The model diagram of the tumor microenvironment. The cross-talk between tumor cells and stromal cells is regulated by different mechanisms: (i) cell-to-cell adhesion between tumor cells and ECM components (i.e., collagens, fibronectin, and laminin)/stromal cells; and (ii) soluble factors, i.e., cytokines, chemokines, growth factors, exosomes, and miRNAs released by the stromal cells and MM cells, with autocrine and paracrine effects. The adhesion of tumor cells and stromal cells is associated with cell surface antigen and antibodies, the expression of the integrin family, discoidin-domain receptors (DDR), cadherin, selectin, etc. As shown here, collagen and other proteins are involved in CAM-DR, while soluble cytokines are usually involved in SM-DR. They contribute to drug-resistance upon engagement with their ligands in the tumor microenvironment. The activation of the signaling pathways involved leads to tumor cell proliferation, anti-apoptosis, and survival, resulting in drug resistance. Inhibitors of related signaling pathways are beneficial to the reversal of drug resistance.

of VLA-4 can subsequently lead to increased drug resistance, whereas the reversal a drug resistance is usually associated with decreased VLA-4 expression (Fontana et al., 2021; Sevilla-Movilla et al., 2020). Most integrins bind to ECM proteins (Hynes, 1992), among which the most important of which is fibronectin, which is the ligand of at least 10 integrin molecules. Cadherins can be classified into several different types including Type I and Type II classical cadherins (Ivanov et al., 2001). Stromal cells upregulate cadherin expression in leukemia cell lines and increase resistance to imatinib by stabilizing $\beta$-catenin (Chen et al., 2014). When interrupted the $\mathrm{N}$-cadherin-mediated adhesion of chronic myeloid leukemia (CML) cells to BMSCs, the tumor cells gained sensitivity toward imatinib treatment (Zhang et al., 2013). Selectins (CD62) are single-chain transmembrane glycoproteins that mediate calcium-dependent carbohydrate-binding (Borsig, 2018). Hematological tumor cells interact with E-selectin through various ligands such as CD43, CD44, and PSGL-1 (Bistrian et al., 2009). Although relatively specific ligands are preferentially bound in different cells, this does not mean that other ligands are less crucial in the CAM-DR of the disease. Interestingly, nilotinib treatment upregulated the expression of E-selectin, which may result in the increased adherence of leukemia cells to E-selectin and the evasion of the cytotoxicity induced by chemotherapy (Hadzijusufovic et al., 2017). Discoidin domain receptors (DDR), including DDR1 and DDR2, are special types of the transmembrane receptor tyrosine kinase superfamily. DDR are activated by binding to the collagen and can activate signal transduction pathways. At the same time, DDR can regulate cell-collagen interactions which involved in multiple processes such as cell proliferation, migration, and apoptosis (Gao et al., 2021). Moreover, the IIGFs-DDR1 crosstalk is considered the major mediator of therapy resistance of cancer cells (Buck et al., 2010; Vella et al., 2019). The model diagram of tumor microenvironment is shown in Figure 1.

On this basis, the simplified model of the tumor microenvironment is to construct the $\mathrm{FN}$ model, that is, the interaction between tumor cells and FN leads to CAM-DR, which is convenient for the study of drug resistance caused by the adhesion of tumor cells to the ECM. At present, the models of CAM-DR have been widely used to simulate the interactions between tumor cells and tumor cells, tumor cells and ECM, and tumor cells and stromal cells. In addition to the FN model, there are also stromal models, which can be used to study CAM-DR and SM-DR. First proposed by the Dalton Laboratory, FN model allows the researchers to investigate the specific signaling pathways of CAM-DR which involved in cell adhesion associated 
with FN or $\beta 1$ integrin activation (Hazlehurst and Dalton, 2001), elucidating the role of two major adhesion molecules, VLA-4 and VLA-5, in hematological malignancies. One of the most typical findings of this model is that the activation of NF- $\kappa B$ signaling by $\mathrm{FN}$ is associated with the occurrence of CAM-DR (Landowski et al., 2003). Using the FN model, it was found for the first time that the down-regulation of the apoptotic protein Bim in myeloma was closely related to CAM-DR. This finding also proved that the integrin-mediated signaling pathway in myeloma is similar to the role of EGFR in the EGFR signaling pathway and can regulate the expression of Bim protein (Hazlehurst et al., 2003). FN adhesion model can also cause cell cycle arrest in the G1 phase, increase the expression of cell cycle inhibitor p27 (Lwin et al., 2007a), and inhibit the activity of CDK2 (Jiang et al., 2000b), a key molecule of cell division. Clinically related studies have found that G1 phase arrest of the cell cycle can significantly reduce the efficacy of drugs (Jiang et al., 2000a). These findings also explain the rapid proliferation of tumor cells in the microenvironment and their insensitivity to cytotoxic drug killing mechanisms. However, the FN model ignores the fact that stromal cells play a more complex role in the tumor microenvironment than fibronectin. The matrix model constructed by the cell compartment culture system can enable researchers to eliminate the interference of SM-DR in the study of CAM-DR, so it creates the condition for the study of CAM-DR in vitro. Similar results were found using the same model as the FN model (Said et al., 2012). Mudry et al. (2000) found that direct interaction with stromal cells, rather than the action of soluble factors, protects leukemic cells from drug-induced apoptosis. Blockage of the vascular cell adhesion molecule-1 (VCAM-1) signaling pathway by anti-VCAM reagents abolished this protective effect, while the FN model was unable to identify whether VLA-4-mediated interactions with VCAM. The drug resistance caused by this interaction is associated with downregulation of the pro-apoptotic molecule caspase-3 (Fortney et al., 2001). In other studies, co-culture of myeloma cells with matrix in conditioned media with soluble factors, rather than just conditioned stromal cells, protected myeloma cells from mitoxantrone drug-mediated apoptosis (Nefedova et al., 2003). However, the cell compartment culture of stromal cells and myeloma cells also produced the phenomenon of drug apoptosis protection, which further supports the interaction between tumor cells and stromal cells as an important part of drug resistance. Although the mechanism of this has not been thoroughly studied, it can be concluded that the adhesion of tumor cells to stromal cells is inseparable from cell cycle arrest and so on to avoid drug-induced apoptosis. The model diagram of CAM-DR research is shown in Figure 2.

In general, the interaction between the tumor microenvironment and tumor cells provides survival signals for tumor cells, regardless through direct contact or the production of soluble factors in the microenvironment. They can upregulate anti-apoptotic molecules, down-regulate pro-apoptotic molecules, promote cell proliferation, reduce DNA damage, and increase DNA repair ability through different signaling pathways (Dehghanifard et al., 2018; Mensah et al., 2018). Therefore, the tumor microenvironment plays an integral role in tumor cell survival and drug response. The intervention of the factors that promote the growth, survival, angiogenesis, and drug resistance of tumor cells in the microenvironment will be a new therapeutic approach in the future (Naci et al., 2015). Some of these drugs have been approved for clinical use (such as Idelalisib and Dactolisib, etc.), while the others are still in clinical trials (such as Buparlisib, Dactolisib, etc.). Related inhibitors based on pre-clinical research provide new insights into the treatment of cancer and this might bring new bright prospects (Sanchez et al., 2019). The sulfonamide derivative E7820, which inhibits $\alpha 2$ integrin subunit gene expression is used in combination with chemotherapy in phase II clinical trials in patients with various advanced or refractory malignancies (Keizer et al., 2011; Mita et al., 2011). A humanized blocking $\mathrm{mAb}$ against 2 integrin chains (GBR-500, Glenmark-Sanofi) has been developed and was well tolerated in phase I clinical trials. GBR-500 can block the local growth of human prostate cancer cell lines in vivo and increases the sensitivity of hepatocarcinoma cell lines to cytotoxic drugs (Naci et al., 2015). Targeted drugs for tumor cells and tumor microenvironment can eliminate or reduce small residual lesions of tumors and reduce acquired drug resistance.

\section{ROLES OF CAM-DR IN TUMORS}

\section{Hematologic Malignancies Multiple Myeloma (MM)}

Multiple myeloma is the second most common hematological malignancy, accounting for about $10 \%$ of all hematological malignancies. It is characterized by abnormal proliferation of plasma cells, secretion of a monoclonal immunoglobulin or its fragments (M protein), resulting in the related organ or tissue damage. The occurrence and development of myeloma are closely related to some special changes of tumor cells, such as genomic/chromosomal instability, gene mutations, chromosome translocations, and the interaction of ECM, that is, the continuous dynamic interaction between myeloma cells and bone marrow microenvironment (Di Marzo et al., 2016). The treatment of myeloma is mainly targeted at tumor cells by chemotherapy and targeted therapy, stem cell transplantation, and symptomatic treatment. However, the 5-year survival rate of $\mathrm{MM}$ is about 40 months from 1990 to 2000 . With the continuous development and clinical application of new drugs such as bortezomib, carfilzomib, lenalidomide, pomalidomide, and so on, the 5-year survival rate of $\mathrm{MM}$ has increased significantly since the beginning of the 21 st century, reaching about 60 months (Furukawa and Kikuchi, 2016). Although the therapeutic drugs for $\mathrm{MM}$ are constantly developing, drug resistance is an important cause of death, resulting in poor prognosis, recurrence, and death. Existing studies have shown that the interaction of myeloma cells and tumor microenvironment plays an important role in the treatment of drug resistance, especially CAM-DR (Di Marzo et al., 2016; Ullah, 2019). The role of the bone marrow microenvironment is to produce a specific phenotype through the regulation of cytokines and direct contact with MM cells, resulting in insensitivity to treatment. 


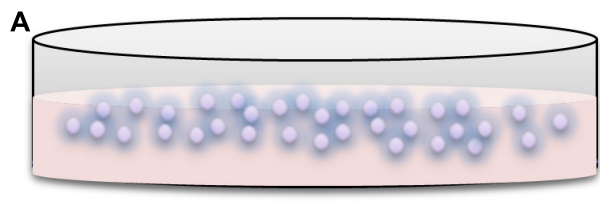

Suspension

C

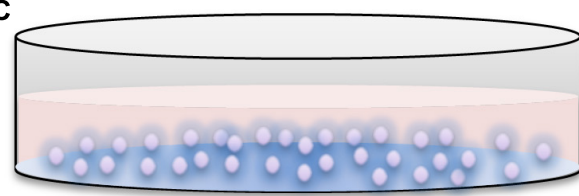

Tumor-FN

E

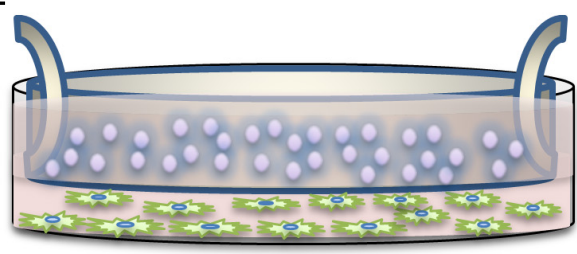

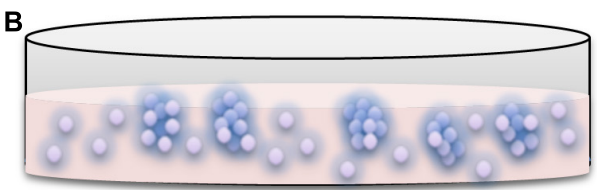

Tumor-tumor

D

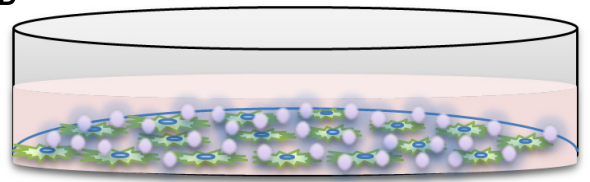

Tumor-BMSC

\section{BMSC}

\section{Tumor cell}

FN

Transwell

FIGURE 2 | The research pattern diagram of CAM-DR. Construction of CAM-DR model in vitro through the construction of FN adhesion model (C) and cell-cell direct adhesion model $(\mathbf{D})$, transwell model $\mathbf{( E )}$ can be used to study the relationship of directly acting soluble factors between cells, organ-like culture model $(\mathbf{B})$ is relatively less used, and simple suspension culture model $(\mathbf{A})$ is used as control.

The molecules involved in CAM-DR in MM are commonly found in some chemokine receptors and integrins, and some cell cycle regulatory factors and apoptosis-related proteins can also be seen. The C-X-C motif chemokine receptors (CXCR) involved in CAM-DR include CXCR4, CXCR7, CXCR12 (Waldschmidt et al., 2017; Wang et al., 2019). They are classical adhesion molecules and homing factors, which are usually highly expressed on the surface of MM cells or BMSCs and can regulate cell-to-cell adhesion independently or mutually. Many upstream molecules usually regulate CAM-DR by regulating chemokine. However, MM can develop from asymptomatic to symptomatic stages, including monoclonal gammopathy of unknown significance (MGUS), smoldering multiple myeloma (SMM), MM, or plasma cell leukemia (Willenbacher et al., 2018). At the same time, CXCR is usually involved not only in CAM-DR but also in the regulation of the biological behavior of other cells, such as the maturation and development of MM cells mentioned above (Ullah, 2019). Studies have shown that in the tumor microenvironment, the adhesion of tumor cells to stromal cells can promote stromal cells to secrete high levels of IL-6, tumor necrosis factor- $\alpha$, and osteopontin as ligands of integrins to bind and activate integrins (Damiano et al., 1999). Previous studies indicated that integrin $\beta 1$ was highly expressed on the cell membrane in MM, and the adhesion of MM cells to ECM mediated by integrin $\beta 1$ could significantly inhibit the apoptosis signal of caspase cells induced by chemotherapeutic drugs
(Rainero and Norman, 2015; Huang et al., 2019). Hazlehurst et al. (2000) also found that integrin $\beta 1$ mediated cell adhesion to ECM cells significantly increased the protein level of cell cycle inhibitory protein $\mathrm{p} 27^{\mathrm{Kip} 1}$, which blocked cells in the G0/G1 phase, thus escaping the killing effect of toxic drugs. The progression of tumors and the emergence of drug resistance are closely related to the NF-кB signaling pathway (Keats et al., 2007). The NF- $\kappa B$ signaling pathway can be activated by cytokines in the tumor cell microenvironment, or by binding to $\mathrm{FN}$ and secreting related factors (Landowski et al., 2003). By blocking the typical/atypical NF-кB pathway and hindering the degradation of Iк $\beta$ protein, bortezomib has become a standard drug in MM therapy (Murray and Norbury, 2000; Gilmore, 2007).

The adhesion of the bone marrow microenvironment in MM not only affects the apoptosis pathway and cell cycle but also leads to some other mechanisms of CAM-DR, including epigenetic mechanisms (Furukawa and Kikuchi, 2016). Previous studies have found that class I histone deacetylases (HDACs) can detect the sensitivity of proteasome inhibitors, and histone methyltransferase EZH2 can regulate the transcriptional activity of anti-apoptotic proteins activated in CAM-DR (Kikuchi et al., 2015). Besides, another histone methyltransferase MMSET can promote the repair of DNA damage and lead to drug resistance (Brito et al., 2009). With more and more in-depth research, more molecular markers have been discovered and studied in the CAM-DR of MM, including microRNAs (miRNAs/miRs) 
(Wang et al., 2011; Wu et al., 2019), exosomes, and cancerassociated fibroblasts (CAFs) (Di Marzo et al., 2016). The disruption of fibronectin-heparan sulfate interactions blocks exosome binding to MM cells or BM stromal cells, highlighting a specific cross-talk fostered by exosomes in the bone marrow microenvironment (Thompson et al., 2013). CAFs can also serve the function of modifying the bone marrow stroma, influencing chemotaxis, adhesion, proliferation, and apoptosis caused by CAM-DR and the expression of adhesion molecules (Frassanito et al., 2014). This article summarizes the CAM-DR of MM (see Table 1).

\section{Non-hodgkin's Lymphoma (NHL)}

Non-Hodgkin's lymphoma is a group of malignant tumors originating from lymph nodes and extranodal lymphoid tissues, accounting for more than $90 \%$ of all lymphomas, including B-cell and NK/T-cell lymphomas. Due to the high heterogeneity of lymphoma, there are more than 60 subtypes of lymphoma, ranging from low-grade malignancy to highly invasive (Li Y. et al., 2015). The malignant degree of T-cell lymphoma is more aggressive than B-NHL, and the treatment lacks specificity. The clinical diagnosis and treatment of B-NHL strictly follow the standard clinical guidelines, but unfortunately, the wide use of monoclonal antibodies has not significantly improved the prognosis of NHL (Lwin et al., 2007b). Based on the recent advances into the tumor microenvironment of $\mathrm{NHL}$, it revealed that CAM-DR is also a crucial factor leading to the recurrence and death (Burger et al., 2009). Studies confirmed that lymphoma cells adhere to BMSCs in the tumor microenvironment to produce a multi-drug resistance (MDR) phenotype, and interrupting this cell adhesion-mediated signal can significantly enhance the sensitivity of tumor cells to chemotherapeutic drugs. When the normal adhesion between malignant tumor cells and the ECM is lost, tumor cells are prone to apoptosis, which is called "anoikis" (Alderton, 2015).

In the related researches of CAM-DR in NHLs, the expressions and functions of characteristic molecules were similar. Despite the common pathological types, there are rare pathological types involving Burkitt's lymphoma (BL) and mantle cell lymphoma (MCL). Adhesion molecules such as surface chemokine receptors CXCR4, CXCR5, and CXCR7 (Kurtova et al., 2009; XargayTorrent et al., 2013) and integrin family molecule Integrin $\alpha 4 \beta 1$ (Takeda et al., 2020) make tumor cells home and stay in matrix niches to escape the killing effect of drugs. Eke and Cordes (2015) found that the signal cascade mediated by integrins and the changes of cell cycle and apoptosis are the main mechanisms of CAM-DR production. The anti-CD49d monoclonal antibody or polypeptide that competitively binds with Integrin $\alpha 4 / \mathrm{CD} 49 \mathrm{~d}$ ligand can inhibit the adhesion of malignant B-NHL cells to stromal cells and enhance the activity of cytotoxic drugs (Takeda et al., 2020).

Due to the diversity of pathological types in lymphomas, the interactions between abnormally expressed molecules are also complex, which also play cross roles in the biological behaviors of NHLs. In particular, they have different regulations on the proliferation of tumor cells. The expression of some molecules can promote the proliferation of tumor cells, and at the same time, CAM-DR is a positive factor of poor prognoses, such as ADAM12, FBP1 (Huang et al., 2016; Yin et al., 2017). Although the expression of some molecules can reduce the proliferation of tumor cells, the production of CAM-DR is consistent with the clinical practice that is not sensitive to the treatment of inert lymphomas, such as DYRK2 (Wang et al., 2015). Some molecules express the proliferation of tumor cells while producing CAM$\mathrm{DR}$, which is consistent with the clinical practice that is not sensitive to the treatment of indolent lymphomas, such as DYRK2. Some molecules can reverse CAM-DR and promote proliferation, which is the research direction of clinical targeted therapeutic intervention, such as CKIP-1 and SGTA (Wang et al., 2014; Zhu et al., 2017). The relevant summary is shown in Table 2.

\section{Leukemia}

Leukemia is a disease characterized by abnormal tumor proliferation of cells in the hematopoietic system and extensive infiltration of extramedullary organs, and abnormal proliferation, differentiation, and apoptosis of peripheral blood leukocytes. It can be divided into different disease types according to the course of the disease, cell morphology, chromosome abnormality, and so on. The specific leukemia subtypes of interest were acute lymphocytic leukemia (ALL), chronic lymphocytic leukemia (CLL), acute myeloid leukemia (AML), and CML (Li et al., 2021). Chemotherapy remains the main treatment of leukemia. With the development of stem cell transplantation technology in recent years, the treatment and prognosis of leukemia have been improved significantly. However, chemotherapy resistance is still a problem that cannot be ignored, which directly leads to insensitivity to first-line treatment or recurrence after short-term remission. The classic drugs for the treatment of leukemia are cell-cycle non-specific killing drugs, which do not have the characteristics of targeted killing of tumor cells. Although the research of targeted drugs is continuously deepening, however, there is still no breakthrough in disease control and prognosis. In contrast, the molecular interaction between the microenvironment and leukemic cells is often ignored (Ruan et al., 2020). Similar to previous myeloma and lymphoma, the tumor microenvironment plays a key role in the treatment of leukemia (Wang et al., 2018; Heath et al., 2019).

Chemotherapeutic resistance in adults with ALL is still an insurmountable problem (Roboz et al., 2014). Although the survival rates of childhood ALL are improving, the recurrence of disease after chemotherapy is still unsolved (Bhojwani et al., 2015). El Azreq et al. (2012) report that collagen/ $\beta 1$ integrin signaling inhibits doxorubicin-induced apoptosis of leukemic $\mathrm{T}$-cells by up-regulating the expression of the ATP-binding cassette C 1 (ABCC1) transporter. Their results indicate for the first time that collagen/ $\beta 1$ integrin/ERK signaling activation could represent a key pathway in T-ALL chemoresistance. In CLL, it has been reported that CAM-DR can activate the phosphatidylinositol 3-kinase (PI3K)/AKT signal pathway, which in turn leads to proliferation (Hoellenriegel et al., 2011). In vitro experiments showed that PI3/Akt signaling pathways were related to poor prognosis and drug resistance, and the reduction 
TABLE 1 | CAM-DR in MM.

\begin{tabular}{|c|c|c|c|c|}
\hline Molecules & Expression level & Biological functions & Signaling pathways & References \\
\hline ANXA7/CDC5L & Up & $\begin{array}{l}\text { Promote the cell cycle, } \\
\text { proliferation, and CAM-DR }\end{array}$ & & Liu et al., 2020 \\
\hline $\mathrm{BTK} / \mathrm{CXCR} 4$ & Up & $\begin{array}{l}\text { Relate to MM progression } \\
\text { and drug resistance }\end{array}$ & & Wang et al., 2019 \\
\hline $\mathrm{p}-\mathrm{EZH} 2$ & Up & $\begin{array}{l}\text { p-EZH2(S21) induce } \\
\text { hypermethylation of } \\
\text { H3K27, lead to the } \\
\text { sustained expression of } \\
\text { antiapoptotic genes }\end{array}$ & IGF-1R/PI3K/AKT & Kikuchi et al., 2015 \\
\hline CXCL12/CXCR7 & Up & Enhance CAM-DR & ERK/MAPK & Waldschmidt et al., 2017 \\
\hline Integrin $\alpha 6 \beta 1$ & Up & $\begin{array}{l}\text { An autocrine mechanism in } \\
\text { CAM-DR }\end{array}$ & Wnt3/RhoA/ROCK & Kobune et al., 2007 \\
\hline Integrin $\beta 7$ & Up & $\begin{array}{l}\text { Enhance CAM-DR, } \\
\text { migration, and BM homing }\end{array}$ & $N F-\kappa B$ & Neri et al., 2011 \\
\hline Integrin $\alpha 4 \beta 1$ & Up & $\begin{array}{l}\text { CAM-DR and inhibit cell } \\
\text { apoptosis }\end{array}$ & $N F-\kappa B$ & $\begin{array}{l}\text { Fontana et al., 2021; } \\
\text { Sevilla-Movilla et al., } 2020\end{array}$ \\
\hline Numbl/Integrin $\beta 1$ & Up & $\begin{array}{l}\text { Regulate cell-cycle } \\
\text { progression }\end{array}$ & $\mathrm{PIOK} / \mathrm{AKT}$ & Huang et al., 2019 \\
\hline p27 & Up & $\begin{array}{l}\text { Regulate cell-cycle } \\
\text { progression }\end{array}$ & & $\begin{array}{l}\text { Hazlehurst et al., 2000; } \\
\text { Zhan et al., } 2007\end{array}$ \\
\hline PDCD4 & Down & $\begin{array}{l}\text { Confer drug resistance via } \\
\text { enhancing AKT } \\
\text { phosphorylation at Ser473 }\end{array}$ & & Wu et al., 2019 \\
\hline CHD1L AGS3 & Up & Anti-apoptotic & Caspase-9/3 & $\begin{array}{l}\text { Shao et al., 2014; Xu et al., } \\
2016\end{array}$ \\
\hline EphA4 & Up & $\begin{array}{l}\text { Promote proliferation via } \\
\text { the regulation of cell cycle } \\
\text { and CAM-DR by enhancing } \\
\text { p-AKT expression }\end{array}$ & & Ding et al., 2017 \\
\hline Kpn $\beta 1$ & Up & $\begin{array}{l}\text { Associate with the } \\
\text { proliferation, interact with } \\
\text { p65, and promote CAM-DR }\end{array}$ & $N F-\kappa B$ & He et al., 2016 \\
\hline RBQ3 ARF1 VPS4B PKM2 GPR37 RUNX2 & Down & $\begin{array}{l}\text { Promote proliferation, } \\
\text { knockdown of molecules } \\
\text { induced CAM-DR }\end{array}$ & PI3K/AKt MAPK/ERK & $\begin{array}{l}\text { Huang et al., 2014; He Y. } \\
\text { et al., 2015; Tang et al., } \\
\text { 2015; Liu et al., 2016; Xu } \\
\text { et al., 2017; Zhang et al., } \\
2020\end{array}$ \\
\hline Homer1b/c & Down & Pro-apoptotic & & Tang et al., 2016 \\
\hline
\end{tabular}

of apoptosis caused by regulatory chemotherapy in pediatric preB ALL (Morishita et al., 2012). In CLL and AML, inhibition of the PI3K/AKT pathway can lead to a decrease in cell proliferation (Billottet et al., 2006; Nguyen et al., 2014). Among the studies of CAM-DR in the hematological tumors mentioned above, it has been found that PI3K/AKT is involved in the occurrence and development of CAM-DR in MM and NHL (Ouyang et al., 2016; Huang et al., 2019). Moreover, in the solid tumor, adhesionmediated activation of the PI3K/AKT pathway has also been reported (Zhu et al., 2012; Toth et al., 2019). Due to the relations between PI3K activation and the unlimited proliferation of tumor cells and CAM-DR,PI3K/AKT has become a promising target in anti-tumor therapies. As part of the combined treatment, the PI3K inhibitors can not only inhibit tumor cell proliferation but also restore sensitivity to other treatments, reduce the occurrence of drug resistance and achieve a synergistic killing effect. Further studies on PI3K/AKT signaling pathway inhibitors have found that inhibition of related signaling pathways can significantly inhibit tumor cell proliferation and enhance chemosensitivity in CLL and AML (Billottet et al., 2006; Nguyen et al., 2014). Some results showed that by inhibiting pro-apoptotic Ras-related C3 botulinum toxin substrate 1 (Rac1), $\alpha 2 \beta 1$ integrin can be a major pathway protecting leukemic cells from genotoxic agents and may thus represent an important therapeutic target in the anti-cancer treatment of AML (Naci et al., 2019). Bruton tyrosine kinase (BTK) inhibitors have also been found to reverse CAM-DR and tumor migration in CML (de Rooij et al., 2012). Fernandez-Vidal et al. (2006) have shown that the inhibition of proliferation and anti-apoptosis induced by adhesion is related to the expression of $\mathrm{M}$-phase inducer phosphatase 1 (CDC25A), while CDC25A participates in the regulation of the cell cycle and activates the PI3K/AKT signal pathway. CDC25A is a bispecific phosphatase, which mainly participates in the G1-S transition of the cell cycle, and plays an important role in the 
TABLE 2 | CAM-DR in NHL.

\begin{tabular}{|c|c|c|c|c|c|}
\hline Tumor type & Molecules & Expression level & Biological functions & Signaling pathways & References \\
\hline $\mathrm{MCL}$ & SOX11 & Up & $\begin{array}{l}\text { Increase migration, } \\
\text { transmigration, } \\
\text { proliferation, and } \\
\text { resistance }\end{array}$ & $\begin{array}{l}\text { FAK/PI3K/AKT } \\
\text { p38/MAPK }\end{array}$ & $\begin{array}{l}\text { Balsas et al., 2017; } \\
\text { Yang et al., } 2020\end{array}$ \\
\hline MCL & CXCL12/CXCR7 & Up & $\begin{array}{l}\text { Enhance CAM-DR } \\
\text { and migration }\end{array}$ & & $\begin{array}{l}\text { Kurtova et al., 2009; } \\
\text { Xargay-Torrent et al., } \\
2013\end{array}$ \\
\hline$B L$ & CD49D/E & Up & Enhance CAM-DR & $N F-\kappa B$ & Takeda et al., 2020 \\
\hline DLBCL & HGF/MET & Up & $\begin{array}{l}\text { Induce } \\
\text { integrin-mediated } \\
\text { adhesion }\end{array}$ & $\begin{array}{l}\text { RAS/MAPK } \\
\text { PI3K/PKB }\end{array}$ & Tjin et al., 2006 \\
\hline DLBCL & ABCG2 & Up & $\begin{array}{l}\text { Increase expression } \\
\text { of the antiapoptotic } \\
\text { proteins }\end{array}$ & & Singh et al., 2011 \\
\hline B-NHL & Integrin $\alpha 4 \beta 1$ & Up & $\begin{array}{l}\text { CAM-DR and inhibit } \\
\text { cell apoptosis }\end{array}$ & & Mraz et al., 2011 \\
\hline B-NHL & $\begin{array}{l}\text { PRMD1 } \\
\text { topoisomerase } \\
\text { ॥ } \beta \text { MDR1 }\end{array}$ & Up & Enhance CAM-DR & & $\begin{array}{l}\text { Hazlehurst et al., 2006; } \\
\text { Lin et al., 2011; Yagi } \\
\text { et al., } 2013\end{array}$ \\
\hline B-NHL & BAFF hPEBP4 & Up & Anti-apoptotic & & $\begin{array}{l}\text { Lwin et al., 2009; Wang } \\
\text { et al., } 2013\end{array}$ \\
\hline $\mathrm{NHL}$ & p27 & Up & $\begin{array}{l}\text { Regulate cell-cycle } \\
\text { arrest }\end{array}$ & & Lwin et al., 2007a \\
\hline $\mathrm{NHL}$ & XIAP & Up & Anti-apoptotic & $N F-\kappa B$ & Lwin et al., 2007b \\
\hline $\mathrm{NHL}$ & HRF/TCTP & Up & $\begin{array}{l}\text { Anti-apoptotic and } \\
\text { enhance CAM-DR }\end{array}$ & & He S. et al., 2015 \\
\hline $\mathrm{NHL}$ & microRNA-181a & Up & Enhance CAM-DR & & Lwin et al., 2010 \\
\hline $\mathrm{NHL}$ & $\begin{array}{l}\text { TRIP6 CKIP-1 } \\
\text { SGTA }\end{array}$ & Down & $\begin{array}{l}\text { Promote } \\
\text { proliferation, } \\
\text { knockdown of } \\
\text { molecules induced } \\
\text { CAM-DR }\end{array}$ & PIЗK/AKT & $\begin{array}{l}\text { Wang et al., 2014; Miao } \\
\text { et al., 2016b; Zhu et al., } \\
2017\end{array}$ \\
\hline $\mathrm{NHL}$ & $\begin{array}{l}\text { DIXDC1 YB-1 } \\
\text { ENO1 Sam68 } \\
\text { ADAM12 FBP1 }\end{array}$ & Up & $\begin{array}{l}\text { Promote } \\
\text { proliferation and } \\
\text { CAM-DR }\end{array}$ & PIЗK/AKT & $\begin{array}{l}\text { Wu et al., 2015; Zhu X. } \\
\text { et al., 2015; Huang } \\
\text { et al., 2016; Miao et al., } \\
\text { 2016a; Ouyang et al., } \\
\text { 2016; Yin et al., } 2017\end{array}$ \\
\hline $\mathrm{NHL}$ & DYRK2 & Up & $\begin{array}{l}\text { Decrease } \\
\text { proliferation but } \\
\text { enhance CAM-DR }\end{array}$ & & Wang et al., 2015 \\
\hline
\end{tabular}

regulation of the cell cycle involving CAM-DR. Previous shreds of evidence suggested that integrins play key roles in the CAM$\mathrm{DR}$ of MM and NHL, and existing studies also indicated that integrin $\alpha 4$ plays a similar role in leukemia's drug resistance (Shishido et al., 2014). Incomplete sensitivity to chemotherapy leads to the persistence of some drug-resistant cells and minimal residual diseases (MRD) (Akabane and Logan, 2020). Interfering integrin $\alpha 4$-mediated cell adhesion can make them sensitive to chemotherapy, thus further promoting the killing effects of all tumor cells in an MRD setting.

\section{Solid Tumors}

The incidence of hepatocellular carcinoma (HCC) is high in Asia. Only about $20 \%$ of patients have the chance of surgical resection, and most patients have a short-term risk of recurrence after surgery (Saito et al., 2019). Despite the development of interventional therapy, targeted therapy, and immunotherapy, the overall prognosis of HCC is still poor and it remains the second leading cause of cancer-related deaths in the world (Ferlay et al., 2015). Moreover, most HCCs are resistant to chemotherapeutic drugs (Wu et al., 2021). With the continuous study of the tumor microenvironment, it is found that CAM-DR in HCC is similar to hematological tumors. In previous studies, it has been found that the adhesion of HepG2 cells to FN can significantly increase the drug resistance of tumor cells, and is closely related to the expression of integrin $\beta 1$ (Zhu et al., 2012). At the same time, some studies have shown that the regulation of connective tissue growth factor (CTGF) and collagen 1A1 (COL1A1) is involved in CAM-DR (Song et al., 2017).

In addition to HHC, CAM-DR is also being investigated in many epithelial tumors. CAM-DR can occur in almost all kinds of tumors. Nakagawa et al. (2014) found that the involvement of integrin $\beta 1$ in the adhesion of tumor cells to FN can lead to 5-Fu resistance in the study of oral squamous cell carcinoma (OSCC). 
In head and neck cancer, a melphalan-resistant nasopharyngeal carcinoma (NPC) cell line shows up-regulation of integrin subunits $\alpha 2, \alpha 5, \alpha 6, \beta 1$, and $\beta 2$ compared with drug-sensitive parent lines. As well as chemoresistance phenotype, this was associated with a significantly stronger binding to ECM and increased invasiveness (Liang et al., 2001). A vinblastineresistant subline of renal carcinoma cells showed increased expression of integrin very late antigen-1/2 and decreased expression of integrin very late antigen-6 in association with increased attachment to collagen and FN (Duensing et al., 1996). Similar results have been found in gastric cancer (GC). MGr1Ag/37LRP (P37-kDa laminin receptor precursor) can promote CAM-DR by activating downstream focal adhesion kinase (FAK)/PI3K and mitogen-activated protein kinase (MAPK) signal pathways through interaction with laminin (Sun et al., 2014b). Common intracellular signals related to integrin binding primarily start with the activation of FAK, recruitment, and activation of Src kinase family, followed by PI3K/Akt pathway or Ras/RAF/MEK/ERK signaling axis, resulting in increased invasion and survival (Li W. et al., 2015; Hou et al., 2016). The mechanistic impact of integrin on chemosensitivity showed high diversity, and a significant increase in MAPK and CREB signal pathways could be found in CAM-DR (Jakubzig et al., 2018). In other words, integrin-mediated matrix binding induces crosstalk with the growth factor signal axis, such as EGFR via FAK or MAPK/ERK pathways triggering proliferation and reducing apoptosis (Jeanes et al., 2012). Although the mechanism of the MAPK/ERK signaling pathway is still relatively thorough compared with the above two pathways, the research of corresponding inhibitors is also relatively small, but it is also believed to be a research direction of the targeted treatment of drug resistance in the future. When human breast cancer cell lines MCF-7 and MDA-MB-231 bind to collagen type 1 (COL1) or $\mathrm{FN}$, they are less sensitive to the cytotoxicity of cisplatin, doxorubicin, and mitoxantrone. CAM-DR is also closely related to the regulation of integrin $\beta 1$ in breast cancer (Baltes et al., 2020). The expression of integrin $\beta 1$ also plays an important role in CAM-DR and is considered to be a potential target for non-small cell lung cancer (NSCLC) (Wang et al., 2020). Adhesion of small-cell lung cancer (SCLC) cells to ECM enhances tumorigenicity and confers resistance to chemotherapeutic agents as a result of $\beta 1$ integrin-stimulated tyrosine kinase activation suppressing chemotherapy-induced apoptosis (Sethi et al., 1999). Strategies based on blocking $\beta 1$ integrin-mediated survival signals may represent a new therapeutic approach to improve the response to chemotherapy in SCLC (Rintoul and Sethi, 2001). In some special types of tumors, researches on CAM-DR have also been conducted, such as glioblastoma multiforme (GBM) and glioma, blocking the interaction between tumor cells and microenvironment can reverse the drug resistance (Westhoff et al., 2008; Ding et al., 2020).

In human reproductive system tumors, hormone receptordependent diseases can be treated with endocrine drugs and/or potential treatments. In reproductive system-related tumors, the primary and acquired drug resistance of endocrine and chemotherapeutic drugs have become the hotspots of current researches (Buttigliero et al., 2015; Lin et al., 2019). In bone-metastatic castration-resistant prostate cancer (CRPC), the interaction between tumor cells and microenvironment combined with hypoxia can lead to the continuous activation of the PI3K signaling pathway, which eventually leads to drug resistance. CAM-DR is mainly regulated by Integrin $\alpha 6 \beta 1$, while hypoxia is related to the regulation of PIM kinase in CRPC (Toth et al., 2019). In ovarian cancer, the expression of Lewis $y$ is significantly high, and it is positively correlated with the expression of some adhesion molecules. The adhesion molecules integrin $\alpha 5$ and integrin $\beta 1$ can be used as independent prognostic factors to judge progression-free survival (PFS) and overall survival (OS) in ovarian cancer (Zhu L.C. et al., 2015). Lewis $y$ inhibits apoptosis and increases CAM-DR in ovarian cancer mainly by activating the FAK signal pathway and inhibiting the BCL-2/BCL-XL pathway (Yan et al., 2015). The above studies on CAM-DR in solid tumors are summarized in Table 3.

\section{THERAPEUTIC DRUGS AND CLINICAL APPLICATION}

\section{Inhibitors}

With the deepening of CAM-DR studies, there are more and more studies on inhibitors. Reversing CAM-DR can significantly improve drug resistance, reduce recurrence, improve the prognosis of patients, and provide a leap forward in clinical treatment. At present, there are some difficulties in targeting molecules. Although there are significant differences in expression, they lack specificity. Some monoclonal antibodies have been proven to be effective in reversing CAM-DR, and the combined use of traditional Chinese medicine can often inhibit the CAM-DR phenomenon. Most studies and clinical applications are related to signal pathway inhibitors (see Table 4 for details).

It has been made clear that the occurrence of CAM-DR is closely related to the activation of related signal pathways, and there are more and more studies on inhibitors of signal pathways. More sophisticated inhibitors of the PI3K/AKT signaling pathway compared to others. In the in vitro experiment, the addition of PI3K inhibitor can significantly reduce the proliferation of tumor cells, reduce the adhesion of tumor cells to the microenvironment, and reverse drug resistance. In the treatment of hematological malignant tumors, the research of PI3K inhibitors presents different stages. The inhibitors approved by FDA are idelalisib, copansilib, and duvelisib. Idelalisib, also known as CAL101, was approved for inert non-Hodgkin's Lymphoma (iNHL) in July 2014 (Miller et al., 2015). The approval is based on the results of a single-arm phase II study in which the overall remission rate (ORR) of idelalisib in patients with follicular lymphoma (FL) and small lymphocytic lymphoma (SLL) was 54 and 58\%, respectively (Furman et al., 2014; Gilbert, 2014). Copanlisib is the second PI3K inhibitor approved for recurrent FL patients by the FDA in September 2017 (Mensah et al., 2018; Tang et al., 2018). Compared with Idelalisib, the high affinity for the p110 subunit of PI3K makes it provide higher specificity and lower gastrointestinal toxicity (Krause et al., 2018). 
TABLE 3 | Roles and mechanisms of CAM-DR in solid tumors.

\begin{tabular}{|c|c|c|c|c|}
\hline Tumor type & Molecules & Biological functions & Signaling pathways & References \\
\hline OSCC & $\mathrm{FN}$ & $\begin{array}{l}\text { Enhance chemosensitivity } \\
\text { to } 5-\mathrm{FU} \text { and apoptosis }\end{array}$ & ILK/Akt/NF-кB & Nakagawa et al., 2014 \\
\hline NPC & $\begin{array}{l}\text { Integrin subunits } \alpha 2 \text {, } \\
\alpha 5, \alpha 6, \beta 1 \text {, and } \beta 2\end{array}$ & $\begin{array}{l}\text { Chemoresistance } \\
\text { phenotype and increase } \\
\text { invasiveness }\end{array}$ & & Liang et al., 2001 \\
\hline $\mathrm{HCC}$ & CTGF/COL1A1 & $\begin{array}{l}\text { Form of compact spheroids } \\
\text { and evade anticancer } \\
\text { therapies }\end{array}$ & & Song et al., 2017 \\
\hline $\mathrm{HCC}$ & Integrin $\beta 1$ & Decrease apoptosis & PI3K/AKT & Zhu et al., 2012 \\
\hline Bone-metastatic CRPC & Integrin $\alpha 6 \beta 1 / \mathrm{PIM}$ & $\begin{array}{l}\text { Promote survival by } \\
\text { reducing oxidative stress } \\
\text { and preventing cell death }\end{array}$ & $\mathrm{PI3K} / \mathrm{mTOR}$ & Toth et al., 2019 \\
\hline $\mathrm{GC}$ & MGr1-Ag/37LRP & $\begin{array}{l}\text { Ligation-induced adhesion } \\
\text { participated in protecting } \\
\text { cells from some apoptotic } \\
\text { stimuli caused by } \\
\text { chemotherapeutic drugs }\end{array}$ & $\begin{array}{l}\text { FAK/PI3K and } \\
\text { ERK/MAPK }\end{array}$ & $\begin{array}{l}\text { Liu et al., 2010; Sun et al., } \\
\text { 2014a,b }\end{array}$ \\
\hline Ovarian cancer & Lewis y & Enhance CAM-DR & FAK & $\begin{array}{l}\text { Yan et al., 2015; Zhu L.C. } \\
\text { et al., } 2015\end{array}$ \\
\hline Breast cancer & Integrin $\beta 1$ & $\begin{array}{l}\text { Transmits breast cancer } \\
\text { cells into chemoresistance }\end{array}$ & ERK/MAPK & Baltes et al., 2020 \\
\hline Breast cancer & Integrin $\beta 1$ & $\begin{array}{l}\text { Inhibits drug-induced } \\
\text { apoptosis by inhibiting the } \\
\text { release of cytochrome c } \\
\text { from the mitochondria }\end{array}$ & PIЗK/AKT & Aoudjit and Vuori, 2001 \\
\hline NSCLC & Integrin $\beta 1$ & $\begin{array}{l}\text { Increase cell viability, } \\
\text { promote migration and } \\
\text { adhesion }\end{array}$ & & Wang et al., 2020 \\
\hline SCLC & Integrin $\beta 1$ & $\begin{array}{l}\text { G2/M cell cycle arrest by } \\
\text { up-regulate p2 } 21^{\text {Cip } 1 / W A F 1} \\
\text { and p27Kip1 and the } \\
\text { down-regulate of cyclins E, } \\
\text { A, and B; prevents } \\
\text { etoposide-induced } \\
\text { caspase-3 activation and } \\
\text { subsequent apoptosis }\end{array}$ & PI3K/AKT & $\begin{array}{l}\text { Hodkinson et al., } 2006 \text {, } \\
2007\end{array}$ \\
\hline GMB & & $\begin{array}{l}\text { Mode of CAM-DR by } \\
\text { forming spheres via cell-cell } \\
\text { interactions }\end{array}$ & $\begin{array}{l}\text { Raf/MEK/ERK and } \\
\text { PI3K/AKT }\end{array}$ & Westhoff et al., 2008 \\
\hline Glioma & $\beta$-catenin & $\begin{array}{l}\text { Enhance cell adhesion } \\
\text { contributed to the } \\
\text { insensitivity to } \\
\text { Temozolomide }\end{array}$ & IP3R1/AKT/ $\beta$-catenin & Ding et al., 2020 \\
\hline
\end{tabular}

Clinical trials of copanlisib are performed in multiple subtypes of NHL in order to further expand its clinical indications. Duvelisib (also known as ABBV-954, INK-1197, and IPI-145) is an oral PI3K inhibitor for the treatment of hematological malignant tumors (Flinn et al., 2018a,b). In September 2018, FDA approved duvelisib for more than two lines of treatment for patients with recurrent/refractory FL and CLL/SLL (Blair, 2018; No author list, 2018). The approval of the FDA is based on the improvement of survival and treatment efficacy of phase III DUO and phase II DYNAMO trials. In the DUO study, the median PFS of CLL/SLL patients receiving drug treatment was 16.4 months and ORR was $78 \%$. In contrast, patients who received CD20 monoclonal antibodies had a median PFS of 9.1 months and an ORR of $39 \%$ (Flinn et al., 2018a). Currently, the researchers are dedicating to develop more PI3K pathway inhibitors, and some inhibitors are also in preliminary clinical trials or in vitro experiments, such as Buparlisib (BKM120) and Dactolisib (BEZ235) (Ragon et al., 2017; Stefanzl et al., 2017). While improving the curative effect, we should also pay more attention to the side effects caused by the inhibitors.

Compared with PI3K inhibitors, NF- $\mathrm{B}$ pathway inhibitors have been widely used in MM, such as bortezomib (BTZ), which induces apoptosis by inhibiting the degradation of

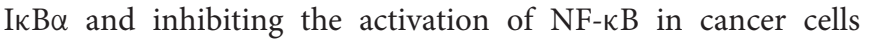
(Murray and Norbury, 2000). As a small molecule NF- $\kappa$ B signal inhibitor, V1810 directly inhibits NF- $\kappa$ B by non-relying on the proteasome mechanism to induce apoptosis of MM cells (Kurland et al., 2001). P38 MAPK inhibitor SB203580 
TABLE 4 | Overview of the targeting drugs.

\begin{tabular}{|c|c|c|c|c|c|c|}
\hline Classification & Name & Disease & Target & Mechanism & Phase & References \\
\hline CXCR4 inhibitors & $\begin{array}{l}\text { Plerixafor } \\
\text { (ADM3100) } \\
\text { BKT140 }\end{array}$ & $\mathrm{MM}$ and $\mathrm{MCL}$ & CXCR4/CXCL12 & $\begin{array}{l}\text { CXCR4 antagonist; } \\
\text { abrogate CXCL12 induced } \\
\text { receptor internalization; } \\
\text { induce MM cell apoptosis }\end{array}$ & Clinical trial & $\begin{array}{l}\text { Kurtova et al., } \\
\text { 2009; Balsas et al., } \\
\text { 2017; Waldschmidt } \\
\text { et al., 2017; Wang } \\
\text { et al., } 2019\end{array}$ \\
\hline \multirow[t]{2}{*}{ Anti-integrin antibody } & Natalizumab & $\begin{array}{l}\mathrm{MM}, \mathrm{MCL} \text {, and } \\
\mathrm{B}-\mathrm{NHL}\end{array}$ & Integrin $\alpha 4 \beta 1 / 7$ & $\begin{array}{l}\text { Non-competitive } \\
\text { antagonism }\end{array}$ & FDA approve & $\begin{array}{l}\text { Kobune et al., } \\
\text { 2007; Mraz et al., } \\
\text { 2011; } \\
\text { Xargay-Torrent } \\
\text { et al., } 2013\end{array}$ \\
\hline & $\begin{array}{l}\text { E7820 } \\
\text { GBR-500 }\end{array}$ & $\mathrm{HCC}$ & Integrin $\alpha 2$ & $\begin{array}{l}\text { Block the local growth and } \\
\text { increases the sensitivity of } \\
\text { cancer cell lines to } \\
\text { cytotoxic drugs }\end{array}$ & $\begin{array}{l}\text { Phase II clinical } \\
\text { trials }\end{array}$ & $\begin{array}{l}\text { Keizer et al., 2011; } \\
\text { Mita et al., 2011; } \\
\text { Naci et al., } 2015\end{array}$ \\
\hline VLA4-nanoparticles & V-NPN-CP & $\mathrm{MM}$ & Integrin $\alpha 4 \beta 1$ & $\begin{array}{l}\text { V-CP: anti-myeloma } \\
\text { effects. V-CP: further } \\
\text { reduced tumor burden and } \\
\text { prolonged survival without } \\
\text { adding to toxicity. }\end{array}$ & In vitro & $\begin{array}{l}\text { Fontana et al., } \\
2021\end{array}$ \\
\hline Selectin inhibitors & $\begin{array}{l}\text { Uproleselan } \\
\text { (GMl-1271) }\end{array}$ & AML & E-selectin & $\begin{array}{l}\text { Small molecule inhibitor } \\
\text { against E-selectin on } \\
\text { endothelial cells }\end{array}$ & In vitro & Barbier et al., 2020 \\
\hline \multirow[t]{3}{*}{ PI3K inhibitors } & $\begin{array}{l}\text { Idelalisib } \\
\text { Copansilib } \\
\text { Duvelisib } \\
\text { Alpelisib } \\
\text { (BYL719) }\end{array}$ & $\begin{array}{l}\text { Leukemia } \\
\text { breast cancer }\end{array}$ & PI3K & $\begin{array}{l}\text { Inhibit PI3K/AKT signaling } \\
\text { pathway }\end{array}$ & FDA approve & $\begin{array}{l}\text { Miller et al., 2015; } \\
\text { Flinn et al., } \\
\text { 2018a,b; Mensah } \\
\text { et al., } 2018\end{array}$ \\
\hline & $\begin{array}{l}\text { Buparlisib } \\
\text { (BKM120) } \\
\text { Dactolisib } \\
\text { (BEZ235) }\end{array}$ & Leukemia & PI3K & $\begin{array}{l}\text { Inhibit PI3K/AKT signaling } \\
\text { pathway }\end{array}$ & Phase I clinical trials & $\begin{array}{l}\text { Ragon et al., 2017; } \\
\text { Stefanzl et al., } 2017\end{array}$ \\
\hline & LY294002 & $\begin{array}{l}\text { MM, NHL, } \\
\text { bone- } \\
\text { metastatic } \\
\text { CRPC, SCLC }\end{array}$ & PI3K & $\begin{array}{l}\text { Inhibit PI3K/AKT signaling } \\
\text { pathway }\end{array}$ & In vitro & $\begin{array}{l}\text { Aoudjit and Vuori, } \\
\text { 2001; Xu et al., } \\
\text { 2017; Huang et al., } \\
\text { 2019; Toth et al., } \\
2019\end{array}$ \\
\hline AKT inhibitors & $\begin{array}{l}\text { MK2206 } \\
\text { PF-04691502 } \\
\text { A6730 }\end{array}$ & $\mathrm{MM}$ and $\mathrm{NHL}$ & AKT & $\begin{array}{l}\text { Inhibit PI3K/AKT signaling } \\
\text { pathway }\end{array}$ & In vitro & $\begin{array}{l}\text { Wu et al., 2015; } \\
\text { Ding et al., 2017; } \\
\text { Zhang et al., } 2020\end{array}$ \\
\hline MAPK inhibitor & $\begin{array}{l}\text { PD98059 } \\
\text { SB203580 }\end{array}$ & MM and MCL & MAPK & $\begin{array}{l}\text { ERK/MAPK signaling } \\
\text { pathway inhibitors }\end{array}$ & In vitro & $\begin{array}{l}\text { Balsas et al., 2017; } \\
\text { Xu et al., 2017; } \\
\text { Yang et al., } 2020\end{array}$ \\
\hline ABCG2/BRCP inhibitor & Fumitremorgin & DLBCL & ABCG2/BRCP & $\begin{array}{l}\text { Abrogate the } \\
\text { stroma-induced } \\
\text { chemotolerance }\end{array}$ & In vitro & Singh et al., 2011 \\
\hline Cyclopamine derivative & $\begin{array}{l}\text { Cyclopamine- } \\
\text { KAAD }\end{array}$ & DLBCL & $\begin{array}{l}\text { Hedgehog } \\
\text { signaling }\end{array}$ & Inhibit hedgehog signaling & In vitro & Singh et al., 2011 \\
\hline Nanomedicine & $\begin{array}{l}\text { PDGFR- } \beta \text { - } \\
\text { doxorubicin }\end{array}$ & Tumors & $\begin{array}{l}\text { Hedgehog } \\
\text { signaling }\end{array}$ & $\begin{array}{l}\text { Increase the binding of } \\
\text { doxorubicin and reduce the } \\
\text { free doxorubicin }\end{array}$ & In vitro & $\begin{array}{l}\text { Prakash et al., } \\
2010\end{array}$ \\
\hline \multirow[t]{5}{*}{ Others } & FNIII14 & OSCC & $\mathrm{FN}$ & $\begin{array}{l}\text { Enhance chemosensitivity } \\
\text { to } 5 \text {-FU and apoptosis }\end{array}$ & In vitro & $\begin{array}{l}\text { Nakagawa et al., } \\
2014\end{array}$ \\
\hline & Losartan & $\mathrm{HCC}$ & CTGF/COL1A1 & $\begin{array}{l}\text { Decrease the form of } \\
\text { compact spheroids }\end{array}$ & In vitro & Song et al., 2017 \\
\hline & Oroxylin A & HCC, glioma & $\beta$-catenin & $\begin{array}{l}\text { inhibit IP3R1/AKT/ } \beta \text {-catenin } \\
\text { pathway }\end{array}$ & In vitro & $\begin{array}{l}\text { Zhu et al., 2012; } \\
\text { Ding et al., } 2020\end{array}$ \\
\hline & $\begin{array}{l}\text { Wenxia } \\
\text { Changfu } \\
\text { formula (WCF) }\end{array}$ & NSCLC & Integrin $\beta 1$ & Decrease cell adhesion & In vitro & Wang et al., 2020 \\
\hline & Carbenoxolone & GMB & & $\begin{array}{l}\text { Sensitize to CD95-induced } \\
\text { apoptosis }\end{array}$ & In vitro & $\begin{array}{l}\text { Westhoff et al., } \\
2008\end{array}$ \\
\hline
\end{tabular}


can inhibit tumor microenvironment-induced proliferation in MCL in vitro (Yang et al., 2020). Although FAK inhibitor (PF) only reduces cell chemotaxis and trans-endothelial migration, the potential ability to prevent tumor cells from bone marrow and lymph node microenvironment protection by recirculation makes it a synergistic drug of AnticD20 or BTZ (Balsas et al., 2017). Strategies designed to target down-stream of cell adhesion molecules such as FAK or integrin linked kinase may eliminate concerns of redundancy of adhesionmediated signaling. Similarly, inhibiting the Janus-activated kinase (JAK)/signal transduction and activator of transcription (STAT) pathway for cytokine signaling maybe more effective comparing to the blockade of a single cytokine receptor (Chen et al., 2020).

\section{Nanomedicine Therapeutic}

Nanomedicine is an emerging form of treatment, which focuses on the delivery of alternative drugs and improvement of therapeutic effects, while reducing harmful side effects on normal tissues. The novel nanomedicines based on the tumor genetic spectrum can design and produce drugs flexibly and quickly, which makes the drug selection of personal treatment more centralized and effective (Khot et al., 2021). With the advanced design and alternative drug delivery mechanisms of different nanodrugs (including liposomes, dendrimers, micelles, carbon-based, polymer conjugates, and metal nanoparticles), overcoming various forms of multidrug resistance looks promising and opens up a new field of vision for cancer treatment (Markman et al., 2013). For example, a unique nano-carrier was made using albumin and a platelet-derived growth factor receptor- $\beta$ (PDGFR- $\beta$ ) recognizing cyclin peptide conjugated to doxorubicin through an acid-sensitive hydrazone linkage. In vivo, the binding of doxorubicin can be increased, and the free doxorubicin can be reduced, thereby reducing the expression of PDGFR- $\beta$, significantly reducing tumor growth (Prakash et al., 2010). A large number of unique nanodrugs have been created and widely studied, and have entered the stage of clinical development. With more discoveries and drug optimization, the advantages of nanodrugs over current treatment options will continue to be enhanced, thus effectively eradicate drugresistant cancers.

\section{REFERENCES}

Akabane, H., and Logan, A. (2020). Clinical significance and management of MRD in adults with acute lymphoblastic leukemia. Clin. Adv. Hematol. Oncol. 18, 413-422.

Alderton, G. K. (2015). Therapeutic resistance: fibroblasts restrain drug sensitivity. Nat. Rev. Cancer 15, 318-319. doi: 10.1038/nrc3965

Aoudjit, F., and Vuori, K. (2001). Integrin signaling inhibits paclitaxel-induced apoptosis in breast cancer cells. Oncogene 20, 4995-5004. doi: 10.1038/sj.onc. 1204554

Balsas, P., Palomero, J., Eguileor, A., Rodriguez, M. L., Vegliante, M. C., PlanasRigol, E., et al. (2017). SOX11 promotes tumor protective microenvironment interactions through CXCR4 and FAK regulation in mantle cell lymphoma. Blood 130, 501-513. doi: 10.1182/blood-2017-04-776740

\section{CONCLUSION AND PROSPECTS}

In the continuous improvement of tumor clinical treatment, drug resistance has become a non-negligible hotspot, which is a key factor for successful treatment. With the advancement and improvement of clinical treatment technology, overcoming drug resistance has become a key issue to improve treatment effect and prognosis of patients. CAM-DR is an important factor in drug resistance caused by the tumor microenvironment. A large number of studies are focusing on CAM-DR, covering hematologic malignant tumors to solid tumors, and the mechanisms insight are gradually being revealed. According to these mechanisms, the study of corresponding inhibitors and combined therapies can reverse the occurrence of drug resistance to a great extent. However, the mechanism of CAMDR is very complex, involving the activation of multiple signal pathways, and the development of corresponding inhibitors and clinical trials are also underway, which is expected to improve the existing treatment to a higher level in the future. With the deepening of CAM-DR research, we believe that overcoming CAM-DR can provide a new method for tumor treatment. Taken together, previous studies demonstrate that CAM-DR is crucial in the drug resistance mechanisms and reversing CAM-DR might provide a promising therapeutic strategy for clinicians.

\section{AUTHOR CONTRIBUTIONS}

$\mathrm{YH}$ and YW collected the related article and finished the manuscript and figures. SJ and $\mathrm{SH}$ gave constructive guidance and made critical revisions. XS participated in the design of this review. JT and SQ revised the manuscript. All authors read and approved the final manuscript.

\section{FUNDING}

This project was supported by grants from the National Natural Science Foundation of China (Nos. 81600158, 81871720, and 82072363) and the National Funds for Distinguished Young Scientists of Nantong City (No. WQ2016057).

Baltes, F., Pfeifer, V., Silbermann, K., Caspers, J., Wantoch von Rekowski, K., Schlesinger, M., et al. (2020). beta1-Integrin binding to collagen type 1 transmits breast cancer cells into chemoresistance by activating ABC efflux transporters. Biochim. Biophys. Acta Mol. Cell Res. 1867:118663. doi: 10.1016/j.bbamcr.2020. 118663

Barbier, V., Erbani, J., Fiveash, C., Davies, J. M., Tay, J., Tallack, M. R., et al. (2020). Endothelial E-selectin inhibition improves acute myeloid leukaemia therapy by disrupting vascular niche-mediated chemoresistance. Nat. Commun. 11:2042. doi: 10.1038/s41467-020-15817-5

Bhojwani, D., Yang, J. J., and Pui, C. H. (2015). Biology of childhood acute lymphoblastic leukemia. Pediatr. Clin. North Am. 62, 47-60. doi: 10.1016/j.pcl. 2014.09.004

Billottet, C., Grandage, V. L., Gale, R. E., Quattropani, A., Rommel, C., Vanhaesebroeck, B., et al. (2006). A selective inhibitor of the p110delta isoform 
of PI 3-kinase inhibits AML cell proliferation and survival and increases the cytotoxic effects of VP16. Oncogene 25, 6648-6659. doi: 10.1038/sj.onc.1209670

Bistrian, R., Dorn, A., Mobest, D. C., Ruster, B., Ludwig, R., Scheele, J., et al. (2009) Shear stress-mediated adhesion of acute myeloid leukemia and KG-1 cells to endothelial cells involves functional P-selectin. Stem Cells Dev. 18, 1235-1242. doi: $10.1089 / \mathrm{scd} .2008 .0380$

Blair, H. A. (2018). Duvelisib: first global approval. Drugs 78, 1847-1853. doi: 10.1007/s40265-018-1013-4

Borsig, L. (2018). Selectins in cancer immunity. Glycobiology 28, 648-655. doi: 10.1093/glycob/cwx105

Brito, J. L., Walker, B., Jenner, M., Dickens, N. J., Brown, N. J., Ross, F. M., et al. (2009). MMSET deregulation affects cell cycle progression and adhesion regulons in $\mathrm{t}(4 ; 14)$ myeloma plasma cells. Haematologica 94, 78-86. doi: 10 . 3324/haematol.13426

Buck, E., Gokhale, P. C., Koujak, S., Brown, E., Eyzaguirre, A., Tao, N., et al. (2010). Compensatory insulin receptor (IR) activation on inhibition of insulin-like growth factor-1 receptor (IGF-1R): rationale for cotargeting IGF-1R and IR in cancer. Mol. Cancer Ther. 9, 2652-2664. doi: 10.1158/1535-7163.MCT-10-0318

Burger, J. A., Ghia, P., Rosenwald, A., and Caligaris-Cappio, F. (2009). The microenvironment in mature B-cell malignancies: a target for new treatment strategies. Blood 114, 3367-3375. doi: 10.1182/blood-2009-06-225326

Buttigliero, C., Tucci, M., Bertaglia, V., Vignani, F., Bironzo, P., Di Maio, M., et al. (2015). Understanding and overcoming the mechanisms of primary and acquired resistance to abiraterone and enzalutamide in castration resistant prostate cancer. Cancer Treat. Rev. 41, 884-892. doi: 10.1016/j.ctrv.2015.08.002

Chen, C., Zhang, H. X., Wang, M., Song, X. G., Cao, J., Wang, L., et al. (2014). Stromal cells attenuate the cytotoxicity of imatinib on Philadelphia chromosome-positive leukemia cells by up-regulating the VE-cadherin/betacatenin signal. Leuk. Res. 38, 1460-1468. doi: 10.1016/j.leukres.2014.09.012

Chen, W. C., Hu, G., and Hazlehurst, L. A. (2020). Contribution of the bone marrow stromal cells in mediating drug resistance in hematopoietic tumors. Curr. Opin. Pharmacol. 54, 36-43. doi: 10.1016/j.coph.2020.08.006

Dalton, W. S. (2003). The tumor microenvironment: focus on myeloma. Cancer Treat. Rev. 29(Suppl. 1), 11-19. doi: 10.1016/s0305-7372(03)00077-x

Damiano, J. S., Cress, A. E., Hazlehurst, L. A., Shtil, A. A., and Dalton, W. S. (1999). Cell adhesion mediated drug resistance (CAM-DR): role of integrins and resistance to apoptosis in human myeloma cell lines. Blood 93, 1658-1667.

de Rooij, M. F., Kuil, A., Geest, C. R., Eldering, E., Chang, B. Y., Buggy, J. J., et al. (2012). The clinically active BTK inhibitor PCI-32765 targets B-cell receptorand chemokine-controlled adhesion and migration in chronic lymphocytic leukemia. Blood 119, 2590-2594. doi: 10.1182/blood-2011-11-390989

Dehghanifard, A., Kaviani, S., Abroun, S., Mehdizadeh, M., Saiedi, S., Maali, A., et al. (2018). Various signaling pathways in multiple myeloma cells and effects of treatment on these pathways. Clin. Lymphoma Myeloma Leuk. 18, 311-320. doi: 10.1016/j.clml.2018.03.007

Di Marzo, L., Desantis, V., Solimando, A. G., Ruggieri, S., Annese, T., Nico, B., et al. (2016). Microenvironment drug resistance in multiple myeloma: emerging new players. Oncotarget 7, 60698-60711. doi: 10.18632/oncotarget.10849

Dias, S., Choy, M., Alitalo, K., and Rafii, S. (2002). Vascular endothelial growth factor (VEGF)-C signaling through FLT-4 (VEGFR-3) mediates leukemic cell proliferation, survival, and resistance to chemotherapy. Blood 99, 2179-2184. doi: 10.1182/blood.v99.6.2179

Ding, L., Shen, Y., Ni, J., Ou, Y., and Liu, H. (2017). EphA4 promotes cell proliferation and cell adhesion-mediated drug resistance via the AKT pathway in multiple myeloma. Tumour Biol. 39:1010428317694298. doi: 10.1177/ 1010428317694298

Ding, Y., Zhou, Y., Li, Z., Zhang, H., Yang, Y., Qin, H., et al. (2020). Oroxylin A reversed Fibronectin-induced glioma insensitivity to Temozolomide by suppressing IP3R1/AKT/beta-catenin pathway. Life Sci. 260:118411. doi: 10. 1016/j.lfs.2020.118411

Duensing, S., Brevis Nunez, F., Meyer, N., Anastassiou, G., Nasarek, A., Grosse, J., et al. (1996). Exposure to vinblastine modulates beta 1 integrin expression and in vitro binding to extracellular matrix molecules in a human renal carcinoma cell line. Invasion Metastasis 16, 65-72.

Eke, I., and Cordes, N. (2015). Focal adhesion signaling and therapy resistance in cancer. Semin. Cancer Biol. 31, 65-75. doi: 10.1016/j.semcancer.2014.0 7.009
El Azreq, M. A., Naci, D., and Aoudjit, F. (2012). Collagen/betal integrin signaling up-regulates the ABCC1/MRP-1 transporter in an ERK/MAPK-dependent manner. Mol. Biol. Cell 23, 3473-3484. doi: 10.1091/mbc.E12-02-0132

Elliott, T., and Sethi, T. (2002). Integrins and extracellular matrix: a novel mechanism of multidrug resistance. Expert Rev. Anticancer Ther. 2, 449-459. doi: 10.1586/14737140.2.4.449

Ferlay, J., Soerjomataram, I., Dikshit, R., Eser, S., Mathers, C., Rebelo, M., et al. (2015). Cancer incidence and mortality worldwide: sources, methods and major patterns in GLOBOCAN 2012. Int. J. Cancer 136, E359-E386. doi: 10.1002/ijc. 29210

Fernandez-Vidal, A., Ysebaert, L., Didier, C., Betous, R., De Toni, F., PradeHoudellier, N., et al. (2006). Cell adhesion regulates CDC25A expression and proliferation in acute myeloid leukemia. Cancer Res. 66, 7128-7135. doi: 10. 1158/0008-5472.CAN-05-2552

Flinn, I. W., Hillmen, P., Montillo, M., Nagy, Z., Illes, A., Etienne, G., et al. (2018a). The phase 3 DUO trial: duvelisib vs ofatumumab in relapsed and refractory CLL/SLL. Blood 132, 2446-2455. doi: 10.1182/blood-2018-05-850461

Flinn, I. W., O’Brien, S., Kahl, B., Patel, M., Oki, Y., Foss, F. F., et al. (2018b). Duvelisib, a novel oral dual inhibitor of PI3K-delta,gamma, is clinically active in advanced hematologic malignancies. Blood 131, 877-887. doi: 10.1182/blood2017-05-786566

Fontana, F., Scott, M. J., Allen, J. S., Yang, X., Cui, G., Pan, D., et al. (2021). VLA4targeted nanoparticles hijack cell adhesion-mediated drug resistance to target refractory myeloma cells and prolong survival. Clin. Cancer Res. 27, 1974-1986. doi: 10.1158/1078-0432.CCR-20-2839

Fortney, J. E., Zhao, W., Wenger, S. L., and Gibson, L. F. (2001). Bone marrow stromal cells regulate caspase 3 activity in leukemic cells during chemotherapy. Leuk. Res. 25, 901-907. doi: 10.1016/S0145-2126(01)00051-0

Frassanito, M. A., Rao, L., Moschetta, M., Ria, R., Di Marzo, L., De Luisi, A., et al. (2014). Bone marrow fibroblasts parallel multiple myeloma progression in patients and mice: in vitro and in vivo studies. Leukemia 28, 904-916. doi: 10.1038/leu.2013.254

Furman, R. R., Sharman, J. P., Coutre, S. E., Cheson, B. D., Pagel, J. M., Hillmen, P., et al. (2014). Idelalisib and rituximab in relapsed chronic lymphocytic leukemia. N. Engl. J. Med. 370, 997-1007. doi: 10.1056/NEJMoa1315226

Furukawa, Y., and Kikuchi, J. (2016). Epigenetic mechanisms of cell adhesionmediated drug resistance in multiple myeloma. Int. J. Hematol. 104, 281-292. doi: 10.1007/s12185-016-2048-5

Galan-Diez, M., Cuesta-Dominguez, A., and Kousteni, S. (2018). The Bone marrow microenvironment in health and myeloid malignancy. Cold Spring Harb. Perspect. Med. 8:a031328. doi: 10.1101/cshperspect.a031328

Gao, Y., Zhou, J., and Li, J. (2021). Discoidin domain receptors orchestrate cancer progression: a focus on cancer therapies. Cancer Sci. 112, 962-969. doi: 10.1111/ cas. 14789

Gilbert, J. A. (2014). Idelalisib: targeting PI3Kdelta in B-cell malignancies. Lancet Oncol. 15:e108. doi: 10.1016/s1470-2045(14)70052-x

Gilmore, T. D. (2007). Multiple myeloma: lusting for NF-kappaB. Cancer Cell 12, 95-97. doi: 10.1016/j.ccr.2007.07.010

Hadzijusufovic, E., Albrecht-Schgoer, K., Huber, K., Hoermann, G., Grebien, F., Eisenwort, G., et al. (2017). Nilotinib-induced vasculopathy: identification of vascular endothelial cells as a primary target site. Leukemia 31, 2388-2397. doi: 10.1038/leu.2017.245

Hazlehurst, L. A., and Dalton, W. S. (2001). Mechanisms associated with cell adhesion mediated drug resistance (CAM-DR) in hematopoietic malignancies. Cancer Metastasis Rev. 20, 43-50. doi: 10.1023/a:1013156407224

Hazlehurst, L. A., Argilagos, R. F., Emmons, M., Boulware, D., Beam, C. A., Sullivan, D. M., et al. (2006). Cell adhesion to fibronectin (CAM-DR) influences acquired mitoxantrone resistance in U937 cells. Cancer Res. 66, 2338-2345. doi: 10.1158/0008-5472.CAN-05-3256

Hazlehurst, L. A., Damiano, J. S., Buyuksal, I., Pledger, W. J., and Dalton, W. S. (2000). Adhesion to fibronectin via betal integrins regulates p27kip1 levels and contributes to cell adhesion mediated drug resistance (CAM-DR). Oncogene 19, 4319-4327. doi: 10.1038/sj.onc. 1203782

Hazlehurst, L. A., Enkemann, S. A., Beam, C. A., Argilagos, R. F., Painter, J., Shain, K. H., et al. (2003). Genotypic and phenotypic comparisons of de novo and acquired melphalan resistance in an isogenic multiple myeloma cell line model. Cancer Res. 63, 7900-7906. 
Hazlehurst, L. A., Valkov, N., Wisner, L., Storey, J. A., Boulware, D., Sullivan, D. M., et al. (2001). Reduction in drug-induced DNA double-strand breaks associated with betal integrin-mediated adhesion correlates with drug resistance in U937 cells. Blood 98, 1897-1903. doi: 10.1182/blood.v98.6.1897

He, S., Huang, Y., Wang, Y., Tang, J., Song, Y., Yu, X., et al. (2015). Histaminereleasing factor/translationally controlled tumor protein plays a role in induced cell adhesion, apoptosis resistance and chemoresistance in non-Hodgkin lymphomas. Leuk. Lymphoma 56, 2153-2161. doi: 10.3109/10428194.2014. 981173

He, S., Miao, X., Wu, Y., Zhu, X., Yin, H., He, Y., et al. (2016). Upregulation of nuclear transporter, Kpnbetal, contributes to accelerated cell proliferationand cell adhesion-mediated drug resistance (CAM-DR) in diffuse large B-cell lymphoma. J. Cancer Res. Clin. Oncol. 142, 561-572. doi: 10.1007/s00432-0152057-4

He, Y., Wang, Y., Liu, H., Xu, X., He, S., Tang, J., et al. (2015). Pyruvate kinase isoform M2 (PKM2) participates in multiple myeloma cell proliferation, adhesion and chemoresistance. Leuk. Res. 39, 1428-1436. doi: 10.1016/j.leukres. 2015.09.019

Heath, J. L., Cohn, G. M., Zaidi, S. K., and Stein, G. S. (2019). The role of cell adhesion in hematopoiesis and leukemogenesis. J. Cell Physiol. 234, 1918919198. doi: 10.1002/jcp. 28636

Hodkinson, P. S., Elliott, T., Wong, W. S., Rintoul, R. C., Mackinnon, A. C., Haslett, C., et al. (2006). ECM overrides DNA damage-induced cell cycle arrest and apoptosis in small-cell lung cancer cells through betal integrin-dependent activation of PI3-kinase. Cell Death Differ. 13, 1776-1788. doi: 10.1038/sj.cdd. 4401849

Hodkinson, P. S., Mackinnon, A. C., and Sethi, T. (2007). Extracellular matrix regulation of drug resistance in small-cell lung cancer. Int. J. Radiat. Biol. 83, 733-741. doi: 10.1080/09553000701570204

Hoellenriegel, J., Meadows, S. A., Sivina, M., Wierda, W. G., Kantarjian, H., Keating, M. J., et al. (2011). The phosphoinositide 3'-kinase delta inhibitor, CAL-101, inhibits B-cell receptor signaling and chemokine networks in chronic lymphocytic leukemia. Blood 118, 3603-3612. doi: 10.1182/blood-2011-05352492

Hou, S., Isaji, T., Hang, Q., Im, S., Fukuda, T., and Gu, J. (2016). Distinct effects of betal integrin on cell proliferation and cellular signaling in MDA-MB-231 breast cancer cells. Sci. Rep. 6:18430. doi: 10.1038/srep18430

Huang, X., Wang, Y., Nan, X., He, S., Xu, X., Zhu, X., et al. (2014). The role of the orphan $G$ protein-coupled receptor 37 (GPR37) in multiple myeloma cells. Leuk. Res. 38, 225-235. doi: 10.1016/j.leukres.2013.11.007

Huang, Y., Huang, X., Cheng, C., Xu, X., Liu, H., Yang, X., et al. (2019). Elucidating the expression and function of Numbl during cell adhesion-mediated drug resistance (CAM-DR) in multiple myeloma (MM). BMC Cancer 19:1269. doi: 10.1186/s12885-019-6446-y

Huang, Y., Xu, X., Ji, L., Wang, Y., Wang, S., Tang, J., et al. (2016). Expression of far upstream element binding protein 1 in Bcell nonHodgkin lymphoma is correlated with tumor growth and celladhesion mediated drug resistance. Mol. Med. Rep. 14, 3759-3768. doi: 10.3892/mmr.2016.5718

Hynes, R. O. (1992). Integrins: versatility, modulation, and signaling in cell adhesion. Cell 69, 11-25. doi: 10.1016/0092-8674(92)90115-s

Ivanov, D. B., Philippova, M. P., and Tkachuk, V. A. (2001). Structure and functions of classical cadherins. Biochemistry 66, 1174-1186. doi: 10.1023/a: 1012445316415

Jakubzig, B., Baltes, F., Henze, S., Schlesinger, M., and Bendas, G. (2018). Mechanisms of matrix-induced chemoresistance of breast cancer cellsdeciphering novel potential targets for a cell sensitization. Cancers 10:495. doi: 10.3390/cancers 10120495

Jeanes, A. I., Wang, P., Moreno-Layseca, P., Paul, N., Cheung, J., Tsang, R., et al. (2012). Specific beta-containing integrins exert differential control on proliferation and two-dimensional collective cell migration in mammary epithelial cells. J. Biol. Chem. 287, 24103-24112. doi: 10.1074/jbc.M112.360834

Jiang, Y., Prosper, F., and Verfaillie, C. M. (2000a). Opposing effects of engagement of integrins and stimulation of cytokine receptors on cell cycle progression of normal human hematopoietic progenitors. Blood 95, 846-854. doi: 10.1182/ blood-2009-06-226373

Jiang, Y., Zhao, R. C., and Verfaillie, C. M. (2000b). Abnormal integrin-mediated regulation of chronic myelogenous leukemia $\mathrm{CD} 34+$ cell proliferation: $\mathrm{BCR} / \mathrm{ABL}$ up-regulates the cyclin-dependent kinase inhibitor, p27Kip, which is relocated to the cell cytoplasm and incapable of regulating cdk2 activity. Proc. Natl. Acad. Sci. U.S.A. 97, 10538-10543. doi: 10.1073/pnas.190104497

Karagiannidis, I., Salataj, E., Said Abu Egal, E., and Beswick, E. J. (2021). G-CSF in tumors: aggressiveness, tumor microenvironment and immune cell regulation. Cytokine 142:155479. doi: 10.1016/j.cyto.2021.155479

Karakasheva, T. A., Lin, E. W., Tang, Q., Qiao, E., Waldron, T. J., Soni, M., et al. (2018). IL-6 mediates cross-talk between tumor cells and activated fibroblasts in the tumor microenvironment. Cancer Res. 78, 4957-4970. doi: 10.1158/00085472.CAN-17-2268

Keats, J. J., Fonseca, R., Chesi, M., Schop, R., Baker, A., Chng, W. J., et al. (2007). Promiscuous mutations activate the noncanonical NF-kappaB pathway in multiple myeloma. Cancer Cell 12, 131-144. doi: 10.1016/j.ccr.2007.07.003

Keizer, R. J., Funahashi, Y., Semba, T., Wanders, J., Beijnen, J. H., Schellens, J. H., et al. (2011). Evaluation of alpha2-integrin expression as a biomarker for tumor growth inhibition for the investigational integrin inhibitor E7820 in preclinical and clinical studies. AAPS J. 13, 230-239. doi: 10.1208/s12248-011-9260-2

Khot, V. M., Salunkhe, A. B., Pricl, S., Bauer, J., Thorat, N. D., and Townley, H. (2021). Nanomedicine-driven molecular targeting, drug delivery, and therapeutic approaches to cancer chemoresistance. Drug Discov. Today 26, 724-739. doi: 10.1016/j.drudis.2020.12.016

Kikuchi, J., Koyama, D., Wada, T., Izumi, T., Hofgaard, P. O., Bogen, B., et al. (2015). Phosphorylation-mediated EZH2 inactivation promotes drug resistance in multiple myeloma. J. Clin. Invest. 125, 4375-4390. doi: 10.1172/JCI80325

Kim, H. N., Ruan, Y., Ogana, H., and Kim, Y. M. (2020). Cadherins, selectins, and integrins in CAM-DR in leukemia. Front. Oncol. 10:592733. doi: 10.3389/fonc. 2020.592733

Kobune, M., Chiba, H., Kato, J., Kato, K., Nakamura, K., Kawano, Y., et al. (2007). Wnt3/RhoA/ROCK signaling pathway is involved in adhesion-mediated drug resistance of multiple myeloma in an autocrine mechanism. Mol. Cancer Ther. 6, 1774-1784. doi: 10.1158/1535-7163.MCT-06-0684

Krause, G., Hassenruck, F., and Hallek, M. (2018). Copanlisib for treatment of B-cell malignancies: the development of a PI3K inhibitor with considerable differences to idelalisib. Drug Des. Dev. Ther. 12, 2577-2590. doi: 10.2147/ DDDT.S142406

Kurland, J. F., Kodym, R., Story, M. D., Spurgers, K. B., McDonnell, T. J., and Meyn, R. E. (2001). NF-kappaB1 (p50) homodimers contribute to transcription of the bcl-2 oncogene. J. Biol. Chem. 276, 45380-45386. doi: 10.1074/jbc.M108294200

Kurtova, A. V., Tamayo, A. T., Ford, R. J., and Burger, J. A. (2009). Mantle cell lymphoma cells express high levels of CXCR4, CXCR5, and VLA-4 (CD49d): importance for interactions with the stromal microenvironment and specific targeting. Blood 113, 4604-4613. doi: 10.1182/blood-2008-10-185827

Landowski, T. H., Olashaw, N. E., Agrawal, D., and Dalton, W. S. (2003). Cell adhesion-mediated drug resistance (CAM-DR) is associated with activation of NF-kappa B (RelB/p50) in myeloma cells. Oncogene 22, 2417-2421. doi: 10.1038/sj.onc. 1206315

Lee, J. W., Chung, H. Y., Ehrlich, L. A., Jelinek, D. F., Callander, N. S., Roodman, G. D., et al. (2004). IL-3 expression by myeloma cells increases both osteoclast formation and growth of myeloma cells. Blood 103, 2308-2315. doi: 10.1182/ blood-2003-06-1992

Li, A. J., Dhanraj, J. P., Lopes, G., and Parker, J. L. (2021). Clinical trial risk in leukemia: biomarkers and trial design. Hematol. Oncol. 39, 105-113. doi: 10.1002/hon.2818

Li, W., Liu, Z., Zhao, C., and Zhai, L. (2015). Binding of MMP-9-degraded fibronectin to beta6 integrin promotes invasion via the FAK-Src-related Erk1/2 and PI3K/Akt/Smad-1/5/8 pathways in breast cancer. Oncol. Rep. 34, 13451352. doi: $10.3892 /$ or. 2015.4103

Li, Y., Wang, Y., Wang, Z., Yi, D., and Ma, S. (2015). Racial differences in three major NHL subtypes: descriptive epidemiology. Cancer Epidemiol. 39, 8-13. doi: 10.1016/j.canep.2014.1 2.001

Li, Z. W., and Dalton, W. S. (2006). Tumor microenvironment and drug resistance in hematologic malignancies. Blood Rev. 20, 333-342. doi: 10.1016/j.blre.2005.0 8.003

Liang, Y., Meleady, P., Cleary, I., McDonnell, S., Connolly, L., and Clynes, M. (2001). Selection with melphalan or paclitaxel (Taxol) yields variants with different patterns of multidrug resistance, integrin expression and in vitro invasiveness. Eur. J. Cancer 37, 1041-1052. doi: 10.1016/s0959-8049(01)00 086-7 
Lin, J., Lwin, T., Zhao, J. J., Tam, W., Choi, Y. S., Moscinski, L. C., et al. (2011). Follicular dendritic cell-induced microRNA-mediated upregulation of PRDM1 and downregulation of BCL- 6 in non-Hodgkin's B-cell lymphomas. Leukemia 25, 145-152. doi: 10.1038/leu.2010.230

Lin, K. K., Harrell, M. I., Oza, A. M., Oaknin, A., Ray-Coquard, I., Tinker, A. V., et al. (2019). BRCA reversion mutations in circulating tumor DNA predict primary and acquired resistance to the PARP inhibitor rucaparib in high-grade ovarian carcinoma. Cancer Discov. 9, 210-219. doi: 10.1158/2159-8290.CD-180715

Liu, H., Ding, L., Shen, Y., Zhong, F., Wang, Q., and Xu, X. (2016). RBQ3 participates in multiple myeloma cell proliferation, adhesion and chemoresistance. Int. J. Biol. Macromol. 91, 115-122. doi: 10.1016/j.ijbiomac. 2016.05.050

Liu, H., Guo, D., Sha, Y., Zhang, C., Jiang, Y., Hong, L., et al. (2020). ANXA7 promotes the cell cycle, proliferation and cell adhesion-mediated drug resistance of multiple myeloma cells by up-regulating CDC5L. Aging 12, 11100-11115. doi: 10.18632/aging.103326

Liu, L., Zhang, H., Sun, L., Gao, Y., Jin, H., Liang, S., et al. (2010). ERK/MAPK activation involves hypoxia-induced MGr1-Ag/37LRP expression and contributes to apoptosis resistance in gastric cancer. Int. J. Cancer 127, 820-829. doi: 10.1002/ijc.25098

Lwin, T., Crespo, L. A., Wu, A., Dessureault, S., Shu, H. B., Moscinski, L. C., et al. (2009). Lymphoma cell adhesion-induced expression of B cell-activating factor of the TNF family in bone marrow stromal cells protects non-Hodgkin's B lymphoma cells from apoptosis. Leukemia 23, 170-177. doi: 10.1038/leu.2008. 266

Lwin, T., Hazlehurst, L. A., Dessureault, S., Lai, R., Bai, W., Sotomayor, E., et al. (2007a). Cell adhesion induces p27Kip1-associated cell-cycle arrest through down-regulation of the SCFSkp2 ubiquitin ligase pathway in mantle-cell and other non-Hodgkin B-cell lymphomas. Blood 110, 1631-1638. doi: 10.1182/ blood-2006-11-060350

Lwin, T., Hazlehurst, L. A., Li, Z., Dessureault, S., Sotomayor, E., Moscinski, L. C., et al. (2007b). Bone marrow stromal cells prevent apoptosis of lymphoma cells by upregulation of anti-apoptotic proteins associated with activation of NFkappaB (RelB/p52) in non-Hodgkin's lymphoma cells. Leukemia 21, 1521-1531. doi: $10.1038 /$ sj.leu. 2404723

Lwin, T., Lin, J., Choi, Y. S., Zhang, X., Moscinski, L. C., Wright, K. L., et al. (2010). Follicular dendritic cell-dependent drug resistance of non-Hodgkin lymphoma involves cell adhesion-mediated Bim down-regulation through induction of microRNA-181a. Blood 116, 5228-5236. doi: 10.1182/blood-2010-03-275925

Malara, A., Currao, M., Gruppi, C., Celesti, G., Viarengo, G., Buracchi, C., et al. (2014). Megakaryocytes contribute to the bone marrow-matrix environment by expressing fibronectin, type IV collagen, and laminin. Stem Cells 32, 926-937. doi: 10.1002/stem.1626

Manier, S., Sacco, A., Leleu, X., Ghobrial, I. M., and Roccaro, A. M. (2012). Bone marrow microenvironment in multiple myeloma progression. J. Biomed. Biotechnol. 2012:157496. doi: 10.1155/2012/157496

Markman, J. L., Rekechenetskiy, A., Holler, E., and Ljubimova, J. Y. (2013). Nanomedicine therapeutic approaches to overcome cancer drug resistance. Adv. Drug Deliv. Rev. 65, 1866-1879. doi: 10.1016/j.addr.2013.09.019

Mensah, F. A., Blaize, J. P., and Bryan, L. J. (2018). Spotlight on copanlisib and its potential in the treatment of relapsed/refractory follicular lymphoma: evidence to date. Oncol. Targets Ther. 11, 4817-4827. doi: 10.2147/OTT.S142264

Miao, X., Wu, Y., Wang, Y., Zhu, X., Yin, H., He, Y., et al. (2016a). Y-box-binding protein-1 (YB-1) promotes cell proliferation, adhesion and drug resistance in diffuse large B-cell lymphoma. Exp. Cell Res. 346, 157-166. doi: 10.1016/j.yexcr.2016.0 7.003

Miao, X., Xu, X., Wu, Y., Zhu, X., Chen, X., Li, C., et al. (2016b). Overexpression of TRIP6 promotes tumor proliferation and reverses cell adhesion-mediated drug resistance (CAM-DR) via regulating nuclear p27(Kip1) expression in nonHodgkin's lymphoma. Tumour Biol. 37, 1369-1378. doi: 10.1007/s13277-0153939-4

Miller, B. W., Przepiorka, D., de Claro, R. A., Lee, K., Nie, L., Simpson, N., et al. (2015). FDA approval: idelalisib monotherapy for the treatment of patients with follicular lymphoma and small lymphocytic lymphoma. Clin. Cancer Res. 21, 1525-1529. doi: 10.1158/1078-0432.CCR-142522
Miranti, C. K., and Brugge, J. S. (2002). Sensing the environment: a historical perspective on integrin signal transduction. Nat. Cell Biol. 4, E83-E90. doi: 10.1038/ncb0402-e83

Mita, M., Kelly, K. R., Mita, A., Ricart, A. D., Romero, O., Tolcher, A., et al. (2011). Phase I study of E7820, an oral inhibitor of integrin alpha-2 expression with antiangiogenic properties, in patients with advanced malignancies. Clin. Cancer Res. 17, 193-200. doi: 10.1158/1078-0432.CCR-10-0010

Morishita, N., Tsukahara, H., Chayama, K., Ishida, T., Washio, K., Miyamura, T., et al. (2012). Activation of Akt is associated with poor prognosis and chemotherapeutic resistance in pediatric B-precursor acute lymphoblastic leukemia. Pediatr. Blood Cancer 59, 83-89. doi: 10.1002/pbc.24034

Mraz, M., Zent, C. S., Church, A. K., Jelinek, D. F., Wu, X., Pospisilova, S., et al. (2011). Bone marrow stromal cells protect lymphoma B-cells from rituximab-induced apoptosis and targeting integrin alpha-4-beta-1 (VLA-4) with natalizumab can overcome this resistance. Br. J. Haematol. 155, 53-64. doi: 10.1111/j.1365-2141.2011.08794.x

Mudry, R. E., Fortney, J. E., York, T., Hall, B. M., and Gibson, L. F. (2000). Stromal cells regulate survival of B-lineage leukemic cells during chemotherapy. Blood 96, 1926-1932. doi: 10.1182/blood.V96.5.1926

Murray, R. Z., and Norbury, C. (2000). Proteasome inhibitors as anti-cancer agents. Anticancer Drugs 11, 407-417. doi: 10.1097/00001813-200007000-00001

Naci, D., Berrazouane, S., Barabe, F., and Aoudjit, F. (2019). Cell adhesion to collagen promotes leukemia resistance to doxorubicin by reducing DNA damage through the inhibition of Racl activation. Sci. Rep. 9:19455. doi: 10. 1038/s41598-019-55934-w

Naci, D., Vuori, K., and Aoudjit, F. (2015). Alpha2beta1 integrin in cancer development and chemoresistance. Semin. Cancer Biol. 35, 145-153. doi: 10. 1016/j.semcancer.2015.08.004

Nakagawa, Y., Nakayama, H., Nagata, M., Yoshida, R., Kawahara, K., Hirosue, A., et al. (2014). Overexpression of fibronectin confers cell adhesion-mediated drug resistance (CAM-DR) against 5-FU in oral squamous cell carcinoma cells. Int. J. Oncol. 44, 1376-1384. doi: 10.3892/ijo.2014.2265

Nefedova, Y., Landowski, T. H., and Dalton, W. S. (2003). Bone marrow stromalderived soluble factors and direct cell contact contribute to de novo drug resistance of myeloma cells by distinct mechanisms. Leukemia 17, 1175-1182. doi: 10.1038/sj.leu.2402924

Neri, P., Ren, L., Azab, A. K., Brentnall, M., Gratton, K., Klimowicz, A. C., et al. (2011). Integrin beta7-mediated regulation of multiple myeloma cell adhesion, migration, and invasion. Blood 117, 6202-6213. doi: 10.1182/blood-2010-06292243

Nguyen, L. X., Sesay, A., and Mitchell, B. S. (2014). Effect of CAL-101, a PI3Kdelta inhibitor, on ribosomal rna synthesis and cell proliferation in acute myeloid leukemia cells. Blood Cancer J. 4:e228. doi: 10.1038/bcj.2014.49

No author list (2018). Duvelisib approved for leukemia, lymphoma. Cancer Discov. 8:OF4. doi: 10.1158/2159-8290.CD-NB2018-137

Oshiro, M. M., Landowski, T. H., Catlett-Falcone, R., Hazlehurst, L. A., Huang, M., Jove, R., et al. (2001). Inhibition of JAK kinase activity enhances Fas-mediated apoptosis but reduces cytotoxic activity of topoisomerase II inhibitors in U266 myeloma cells. Clin. Cancer Res. 7, 4262-4271.

Ouyang, Y., Zhong, F., Wang, Q., Ding, L., Zhang, P., Chen, L., et al. (2016). DIXDC1 promotes tumor proliferation and cell adhesion mediated drug resistance (CAM-DR) via enhancing p-Akt in Non-Hodgkin's lymphomas. Leuk. Res. 50, 104-111. doi: 10.1016/j.leukres.2016.09.011

Prakash, J., de Jong, E., Post, E., Gouw, A. S., Beljaars, L., and Poelstra, K. (2010). A novel approach to deliver anticancer drugs to key cell types in tumors using a PDGF receptor-binding cyclic peptide containing carrier. J. Control Release 145, 91-101. doi: 10.1016/j.jconrel.2010.03.018

Ragon, B. K., Kantarjian, H., Jabbour, E., Ravandi, F., Cortes, J., Borthakur, G., et al. (2017). Buparlisib, a PI3K inhibitor, demonstrates acceptable tolerability and preliminary activity in a phase I trial of patients with advanced leukemias. Am. J. Hematol. 92, 7-11. doi: 10.1002/ajh.24568

Rainero, E., and Norman, J. C. (2015). Endosomal integrin signals for survival. Nat. Cell Biol. 17, 1373-1375. doi: 10.1038/ncb3261

Rintoul, R. C., and Sethi, T. (2001). The role of extracellular matrix in small-cell lung cancer. Lancet Oncol. 2, 437-442. doi: 10.1016/S1470-2045(00)00421-6

Roboz, G. J., Jabbour, E. J., Faderl, S., and Douer, D. (2014). Advances in the treatment of relapsed/refractory acute lymphoblastic leukemia: a case study compendium. Clin. Adv. Hematol. Oncol. 12, 8-18. 
Ruan, Y., Kim, H. N., Ogana, H., and Kim, Y. M. (2020). Wnt signaling in leukemia and its bone marrow microenvironment. Int. J. Mol. Sci. 21:6247. doi: $10.3390 /$ ijms 21176247

Said, G., Guilbert, M., Morjani, H., Garnotel, R., Jeannesson, P., and El Btaouri, H. (2012). Extracellular matrix proteins modulate antimigratory and apoptotic effects of Doxorubicin. Chemother. Res. Pract. 2012:268681. doi: 10.1155/2012/ 268681

Saito, R., Amemiya, H., Hosomura, N., Kawaida, H., Maruyama, S., Shimizu, H., et al. (2019). Prognostic factors for post-recurrent survival in hepatocellular carcinoma after curative resection. Anticancer Res. 39, 3033-3038. doi: 10. 21873/anticanres.13436

Sanchez, V. E., Nichols, C., Kim, H. N., Gang, E. J., and Kim, Y. M. (2019). Targeting PI3K signaling in acute lymphoblastic leukemia. Int. J. Mol. Sci. 20:412. doi: 10.3390/ijms20020412

Sethi, T., Rintoul, R. C., Moore, S. M., MacKinnon, A. C., Salter, D., Choo, C., et al. (1999). Extracellular matrix proteins protect small cell lung cancer cells against apoptosis: a mechanism for small cell lung cancer growth and drug resistance in vivo. Nat. Med. 5, 662-668. doi: 10.1038/9511

Sevilla-Movilla, S., Arellano-Sanchez, N., Martinez-Moreno, M., Gajate, C., Sanchez-Vencells, A., Valcarcel, L. V., et al. (2020). Upregulated expression and function of the alpha4betal integrin in multiple myeloma cells resistant to bortezomib. J. Pathol. 252, 29-40. doi: 10.1002/path.5480

Shain, K. H., Landowski, T. H., and Dalton, W. S. (2002). Adhesionmediated intracellular redistribution of c-Fas-associated death domain-like IL-1-converting enzyme-like inhibitory protein-long confers resistance to CD95-induced apoptosis in hematopoietic cancer cell lines. J. Immunol. 168, 2544-2553. doi: 10.4049/jimmunol.168.5.2544

Shao, S., Huang, X., Wang, Y., He, S., Xu, X., Zhu, X., et al. (2014). A role for activator of G-protein signaling 3 (AGS3) in multiple myeloma. Int. J. Hematol. 99, 57-68. doi: 10.1007/s12185-013-1484-8

Shishido, S., Bonig, H., and Kim, Y. M. (2014). Role of integrin alpha4 in drug resistance of leukemia. Front. Oncol. 4:99. doi: 10.3389/fonc.2014.00099

Singh, R. R., Kunkalla, K., Qu, C., Schlette, E., Neelapu, S. S., Samaniego, F., et al. (2011). ABCG2 is a direct transcriptional target of hedgehog signaling and involved in stroma-induced drug tolerance in diffuse large B-cell lymphoma. Oncogene 30, 4874-4886. doi: 10.1038/onc.2011.195

Song, Y., Kim, J. S., Choi, E. K., Kim, J., Kim, K. M., and Seo, H. R. (2017). TGF-beta-independent CTGF induction regulates cell adhesion mediated drug resistance by increasing collagen I in HCC. Oncotarget 8, 21650-21662. doi: 10.18632/oncotarget.15521

Stefanzl, G., Berger, D., Cerny-Reiterer, S., Blatt, K., Eisenwort, G., Sperr, W. R., et al. (2017). The pan-BCL-2-blocker obatoclax (GX15-070) and the PI3kinase/mTOR-inhibitor BEZ235 produce cooperative growth-inhibitory effects in ALL cells. Oncotarget 8, 67709-67722. doi: 10.18632/oncotarget.18810

Sun, L., Liu, L., Liu, X., Wang, Y., Li, M., Yao, L., et al. (2014a). Gastric cancer cell adhesion to laminin enhances acquired chemotherapeutic drug resistance mediated by MGr1-Ag/37LRP. Oncol. Rep. 32, 105-114. doi: 10.3892/or.2014. 3184

Sun, L., Liu, L., Liu, X., Wang, Y., Li, M., Yao, L., et al. (2014b). MGr1-Ag/37LRP induces cell adhesion-mediated drug resistance through FAK/PI3K and MAPK pathway in gastric cancer. Cancer Sci. 105, 651-659. doi: 10.1111/cas.12414

Takeda, T., Tsubak, M., Genno, S., Matsuda, T., Yamamoto, Y., Ueda, E., et al. (2020). CD49d and CD49e induce cell adhesion-mediated drug resistance through the nuclear factor-kappaB pathway in Burkitt lymphoma. J. Physiol. Pharmacol. 71. doi: 10.26402/jpp.2020.4.02 [Epub ahead of print].

Tang, J., Ji, L., Wang, Y., Huang, Y., Yin, H., He, Y., et al. (2015). Cell adhesion down-regulates the expression of vacuolar protein sorting 4B (VPS4B) and contributes to drug resistance in multiple myeloma cells. Int. J. Hematol. 102, 25-34. doi: 10.1007/s12185-015-1783-3

Tang, J., Zhou, H., Wang, C., Fei, X., Zhu, L., Huang, Y., et al. (2016). Cell adhesion downregulates the expression of Homer $1 \mathrm{~b} / \mathrm{c}$ and contributes to drug resistance in multiple myeloma cells. Oncol. Rep. 35, 1875-1883. doi: 10.3892/or.2015. 4532

Tang, L. A., Dixon, B. N., Maples, K. T., Poppiti, K. M., and Peterson, T. J. (2018). Current and investigational agents targeting the phosphoinositide 3-kinase pathway. Pharmacotherapy 38, 1058-1067. doi: 10.1002/phar.2173

Thompson, C. A., Purushothaman, A., Ramani, V. C., Vlodavsky, I., and Sanderson, R. D. (2013). Heparanase regulates secretion, composition, and function of tumor cell-derived exosomes. J. Biol. Chem. 288, 10093-10099. doi: 10.1074/jbc.C112.444562

Tjin, E. P., Groen, R. W., Vogelzang, I., Derksen, P. W., Klok, M. D., Meijer, H. P., et al. (2006). Functional analysis of HGF/MET signaling and aberrant HGF-activator expression in diffuse large B-cell lymphoma. Blood 107, 760-768. doi: 10.1182/blood-2005-05-1929

Toth, R. K., Tran, J. D., Muldong, M. T., Nollet, E. A., Schulz, V. V., Jensen, C. C., et al. (2019). Hypoxia-induced PIM kinase and laminin-activated integrin alpha6 mediate resistance to PI3K inhibitors in bone-metastatic CRPC. Am. J. Clin. Exp. Urol. 7, 297-312.

Ullah, T. R. (2019). The role of CXCR4 in multiple myeloma: cells' journey from bone marrow to beyond. J. Bone Oncol. 17, 100253. doi: 10.1016/j.jbo.2019. 100253

Vedenko, A., Panara, K., Goldstein, G., Ramasamy, R., and Arora, H. (2020). Tumor microenvironment and nitric oxide: concepts and mechanisms. Adv. Exp. Med. Biol. 1277, 143-158. doi: 10.1007/978-3-030-50224-9_10

Vella, V., Malaguarnera, R., Nicolosi, M. L., Morrione, A., and Belfiore, A. (2019). Insulin/IGF signaling and discoidin domain receptors: an emerging functional connection. Biochim. Biophys. Acta Mol. Cell Res. 1866:118522. doi: 10.1016/j. bbamcr.2019.118522

Waldschmidt, J. M., Simon, A., Wider, D., Muller, S. J., Follo, M., Ihorst, G., et al. (2017). CXCL12 and CXCR7 are relevant targets to reverse cell adhesionmediated drug resistance in multiple myeloma. Br. J. Haematol. 179, 36-49. doi: 10.1111/bjh.14807

Wang, J., Liu, X., Qiu, Y., Shi, Y., Cai, J., Wang, B., et al. (2018). Cell adhesionmediated mitochondria transfer contributes to mesenchymal stem cell-induced chemoresistance on T cell acute lymphoblastic leukemia cells. J. Hematol. Oncol. 11:11. doi: 10.1186/s13045-018-0554-z

Wang, K., Jiang, Y., Zheng, W., Liu, Z., Li, H., Lou, J., et al. (2013). Silencing of human phosphatidylethanolamine-binding protein 4 enhances rituximabinduced death and chemosensitization in B-cell lymphoma. PLoS One 8:e56829. doi: 10.1371/journal.pone.0056829

Wang, M. R., Chen, R. J., Zhao, F., Zhang, H. H., Bi, Q. Y., Zhang, Y. N., et al. (2020). Effect of wenxia changfu formula combined with cisplatin reversing non-small cell lung cancer cell adhesion-mediated drug resistance. Front. Pharmacol. 11:500137. doi: 10.3389/fphar.2020.500137

Wang, W., Wei, R., Liu, S., Qiao, L., Hou, J., Gu, C., et al. (2019). BTK induces CAM-DR through regulation of CXCR4 degradation in multiple myeloma. Am. J. Transl. Res. 11, 4139-4150.

Wang, X., Li, C., Ju, S., Wang, Y., Wang, H., and Zhong, R. (2011). Myeloma cell adhesion to bone marrow stromal cells confers drug resistance by microRNA21 up-regulation. Leuk. Lymphoma 52, 1991-1998. doi: 10.3109/10428194.2011. 591004

Wang, Y., Huang, Y., Xu, X., Tang, J., Huang, X., Zhu, J., et al. (2014). Expression of small glutamine-rich TPR-containing protein A (SGTA) in Non-Hodgkin's Lymphomas promotes tumor proliferation and reverses cell adhesion-mediated drug resistance (CAM-DR). Leuk. Res. 38, 955-963. doi: 10.1016/j.leukres.2014. 05.013

Wang, Y., Wu, Y., Miao, X., Zhu, X., He, Y., Zhong, F., et al. (2015). Silencing of DYRK2 increases cell proliferation but reverses CAM-DR in Non-Hodgkin's Lymphoma. Int. J. Biol. Macromol. 81, 809-817. doi: 10.1016/j.ijbiomac.2015. 08.067

Westhoff, M. A., Zhou, S., Bachem, M. G., Debatin, K. M., and Fulda, S. (2008). Identification of a novel switch in the dominant forms of cell adhesionmediated drug resistance in glioblastoma cells. Oncogene 27, 5169-5181. doi: 10.1038/onc. 2008.148

Willenbacher, W., Seeber, A., Steiner, N., Willenbacher, E., Gatalica, Z., Swensen, J., et al. (2018). Towards molecular profiling in multiple myeloma: a literature review and early indications of its efficacy for informing treatment strategies. Int. J. Mol. Sci. 19:2087. doi: 10.3390/ijms19072087

Wu, Y., Xu, X., Miao, X., Zhu, X., Yin, H., He, Y., et al. (2015) Sam68 regulates cell proliferation and cell adhesion-mediated drug resistance (CAM-DR) via the AKT pathway in nonHodgkin's lymphoma. Cell Prolif. 48, 682-690. doi: 10.1111/cpr.1 2220

Wu, Y., Zhang, J., and Li, Q. (2021). Autophagy, an accomplice or antagonist of drug resistance in HCC? Cell Death Dis. 12:266. doi: 10.1038/s41419-02103553-7 
Wu, Y., Zhu, X., Shen, R., Huang, J., Xu, X., and He, S. (2019). miR-182 contributes to cell adhesion-mediated drug resistance in multiple myeloma via targeting PDCD4. Pathol. Res. Pract. 215:152603. doi: 10.1016/j.prp.2019.152603

Xargay-Torrent, S., Lopez-Guerra, M., Montraveta, A., Saborit-Villarroya, I., Rosich, L., Navarro, A., et al. (2013). Sorafenib inhibits cell migration and stroma-mediated bortezomib resistance by interfering B-cell receptor signaling and protein translation in mantle cell lymphoma. Clin. Cancer Res. 19, 586-597. doi: 10.1158/1078-0432.CCR-12-1935

Xu, X., He, Y., Miao, X., Wu, Y., Han, J., Wang, Q., et al. (2016). Cell adhesion induces overexpression of chromodomain helicase/ATPase DNA binding protein 1-like gene (CHD1L) and contributes to cell adhesion-mediated drug resistance (CAM-DR) in multiple myeloma cells. Leuk. Res. 47, 54-62. doi: 10.1016/j.leukres.2016.05.007

Xu, X., Wang, Q., He, Y., Ding, L., Zhong, F., Ou, Y., et al. (2017). ADP-ribosylation factor 1 (ARF1) takes part in cell proliferation and cell adhesion-mediated drug resistance (CAM-DR). Ann. Hematol. 96, 847-858. doi: 10.1007/s00277-0172949-2

Yagi, K., Yamamoto, K., Umeda, S., Abe, S., Suzuki, S., Onishi, I., et al. (2013). Expression of multidrug resistance 1 gene in B-cell lymphomas: association with follicular dendritic cells. Histopathology 62, 414-420. doi: 10.1111/his. 12035

Yan, L., Wang, C., Lin, B., Liu, J., Liu, D., Hou, R., et al. (2015). Lewis y enhances CAM-DR in ovarian cancer cells by activating the FAK signaling pathway and upregulating Bcl-2/Bcl-XL expression. Biochimie 113, 17-25. doi: 10.1016/j. biochi.2015.01.013

Yang, R., Huo, Z., Duan, Y., Tong, W., Zheng, Y., Su, Y., et al. (2020). SOX11 inhibits tumor proliferation and promotes cell adhesion mediateddrug resistance via a CD43 dependent manner in mantle cell lymphoma. Leuk. Lymphoma 61, 2068-2081. doi: 10.1080/10428194.2020.1762877

Yin, H., Zhong, F., Ouyang, Y., Wang, Q., Ding, L., and He, S. (2017). Upregulation of ADAM12 contributes to accelerated cell proliferation and cell adhesion-mediated drug resistance (CAM-DR) in Non-Hodgkin's Lymphoma. Hematology 22, 527-535. doi: 10.1080/10245332.2017.1312205

Zhan, F., Colla, S., Wu, X., Chen, B., Stewart, J. P., Kuehl, W. M., et al. (2007). CKS1B, overexpressed in aggressive disease, regulates multiple myeloma growth and survival through SKP2- and p27Kip1-dependent and -independent mechanisms. Blood 109, 4995-5001.

Zhang, B., Li, M., McDonald, T., Holyoake, T. L., Moon, R. T., Campana, D., et al. (2013). Microenvironmental protection of CML stem and progenitor cells from tyrosine kinase inhibitors through $\mathrm{N}$-cadherin and Wnt-beta-catenin signaling. Blood 121, 1824-1838. doi: 10.1182/blood-2012-02-412890
Zhang, P. P., Wang, Y. C., Cheng, C., Zhang, F., Ding, D. Z., and Chen, D. K. (2020). Runt-related transcription factor 2 influences cell adhesion-mediated drug resistance and cell proliferation in B-cell non-Hodgkin's lymphoma and multiple myeloma. Leuk. Res. 92:106340. doi: 10.1016/j.leukres.2020.106340

Zhang, P., Zhang, C., Li, J., Han, J., Liu, X., and Yang, H. (2019). The physical microenvironment of hematopoietic stem cells and its emerging roles in engineering applications. Stem Cell Res. Ther. 10:327. doi: 10.1186/s13287-0191422-7

Zhao, M., Tao, F., Venkatraman, A., Li, Z., Smith, S. E., Unruh, J., et al. (2019). N-Cadherin-expressing bone and marrow stromal progenitor cells maintain reserve hematopoietic stem cells. Cell Rep. 26, 652-669.e6. doi: 10.1016/j.celrep.2018.12.093

Zhu, B., Zhao, L., Zhu, L., Wang, H., Sha, Y., Yao, J., et al. (2012). Oroxylin A reverses CAM-DR of HepG2 cells by suppressing Integrinbeta1 and its related pathway. Toxicol. Appl. Pharmacol. 259, 387-394. doi: 10.1016/j.taap.2012.0 1.019

Zhu, L. C., Gao, J., Hu, Z. H., Schwab, C. L., Zhuang, H. Y., Tan, M. Z., et al. (2015). Membranous expressions of Lewis y and CAM-DR-related markers are independent factors of chemotherapy resistance and poor prognosis in epithelial ovarian cancer. Am. J. Cancer Res. 5, 830-843.

Zhu, X., Miao, X., Wu, Y., Li, C., Guo, Y., Liu, Y., et al. (2015). ENO1 promotes tumor proliferation and cell adhesion mediated drug resistance (CAM-DR) in Non-Hodgkin's Lymphomas. Exp. Cell Res. 335, 216-223. doi: 10.1016/j.yexcr.2015.0 5.020

Zhu, X., Ouyang, Y., Zhong, F., Wang, Q., Ding, L., Zhang, P., et al. (2017). Silencing of CKIP-1 promotes tumor proliferation and cell adhesion-mediated drug resistance via regulating AKT activity in nonHodgkin's lymphoma. Oncol. Rep. 37, 622-630. doi: 10.3892/or.2016. 5233

Conflict of Interest: The authors declare that the research was conducted in the absence of any commercial or financial relationships that could be construed as a potential conflict of interest.

Copyright (c) 2021 Huang, Wang, Tang, Qin, Shen, He and Ju. This is an open-access article distributed under the terms of the Creative Commons Attribution License (CC BY). The use, distribution or reproduction in other forums is permitted, provided the original author(s) and the copyright owner(s) are credited and that the original publication in this journal is cited, in accordance with accepted academic practice. No use, distribution or reproduction is permitted which does not comply with these terms. 